Review

\title{
Extremophilic Fungi from Marine Environments: Underexplored Sources of Antitumor, Anti-Infective and Other Biologically Active Agents
}

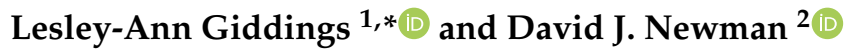 \\ 1 Department of Chemistry, Smith College, 100 Green St., Northampton, MA 01063, USA \\ 2 NIH Special Volunteer, Wayne, PA 19087, USA; djnewman664@verizon.net \\ * Correspondence: lgiddings@smith.edu
}

Citation: Giddings, L.-A.; Newman, D.J. Extremophilic Fungi from Marine Environments: Underexplored Sources of Antitumor, Anti-Infective and Other Biologically Active Agents. Mar. Drugs 2022, 20, 62. https://doi.org/10.3390/ md20010062

Academic Editor: Bill J. Baker

Received: 13 December 2021

Accepted: 7 January 2022

Published: 10 January 2022

Publisher's Note: MDPI stays neutral with regard to jurisdictional claims in published maps and institutional affiliations.

Copyright: (c) 2022 by the authors. Licensee MDPI, Basel, Switzerland. This article is an open access article distributed under the terms and conditions of the Creative Commons Attribution (CC BY) license (https:// creativecommons.org/licenses/by/ $4.0 /)$.

\begin{abstract}
Marine environments are underexplored terrains containing fungi that produce a diversity of natural products given unique environmental pressures and nutrients. While bacteria are commonly the most studied microorganism for natural products in the marine world, marine fungi are also abundant but remain an untapped source of bioactive metabolites. Given that their terrestrial counterparts have been a source of many blockbuster antitumor agents and anti-infectives, including camptothecin, the penicillins, and cyclosporin A, marine fungi also have the potential to produce new chemical scaffolds as leads to potential drugs. Fungi are more phylogenetically diverse than bacteria and have larger genomes that contain many silent biosynthetic gene clusters involved in making bioactive compounds. However, less than $5 \%$ of all known fungi have been cultivated under standard laboratory conditions. While the number of reported natural products from marine fungi is steadily increasing, their number is still significantly lower compared to those reported from their bacterial counterparts. Herein, we discuss many varied cytotoxic and anti-infective fungal metabolites isolated from extreme marine environments, including symbiotic associations as well as extreme pressures, temperatures, salinity, and light. We also discuss cultivation strategies that can be used to produce new bioactive metabolites or increase their production. This review presents a large number of reported structures though, at times, only a few of a large number of related structures are shown.
\end{abstract}

Keywords: extreme environments; marine fungi; bioactive compounds; marine natural products; fungal cultivation strategies

\section{Introduction}

Natural products have been a rich source of therapeutics since the beginning of civilization. To date, $\sim 60 \%$ of all small-molecule drugs approved by the US Food and Drug Administration (FDA), or their equivalent in other countries, have been inspired by these secondary metabolites [1]. Many are anti-infectives and antitumor agents that have been isolated from microbes, including those with symbiotic associations. While microbes are a prolific source of bioactive molecules used to treat cancer and infectious diseases, chemists have been repetitively rediscovering natural products, thus leading to the requirement for a system for the rapid dereplication of known compounds and/or their close relatives. Microbes usually express fewer biosynthetic gene clusters (BGCs) when grown under standard laboratory conditions, even though they have the genetic potential to express more secondary metabolic BGCs. To circumvent these limitations, scientists are either cultivating microbes under nominally non-standard laboratory conditions to activate the expression of cryptic BGCs [2], using genetic engineering and 'omics methods to identify and directly express BGCs [3], or they are isolating microbes from understudied environments [4].

Extreme ecosystems represent new frontiers for drug discovery, as these locations contain unique environmental variables that are not found in mesophilic locales and 
influence microbial metabolism. Extreme environments have been underexplored due to the challenges in accessing these locales. However, more sampling tools and techniques have been developed to study marine environments, presenting new opportunities for exploration. The marine world is vast, covering $\sim 70 \%$ of Earth, including some of the most extreme ecosystems on the planet. Extreme marine environments are characterized as having high pressures, and temperatures that can range from close to freezing to over $250{ }^{\circ} \mathrm{C}$ at the "black smokers", severe ultraviolet radiation, high salt or metal concentrations, symbiosis, or more than one combination of these variables. Microbes constitute much of the biomass in the sea and are prominent producers of secondary metabolites, with a wide range of potent bioactivities against tumor cells and other pathogens, plus potential in other diseases. Thus, bioprospecting these environments for new drugs is an attractive prospect, especially as marine natural products have high hit rates in a broad range of bioassays, with many in clinical and preclinical trials. For a current assessment, the web site, www.marinepharmacology.org (accessed on 12 December 2021), is kept up to date, covering approved drugs from marine sources and compounds that are in clinical trials from Phase I to Phase III plus selected preclinical candidates. Most of the information is from the NIH trials database (www.clinicaltrials.gov accessed on 12 December 2021), but it also includes data from comparable databases from other countries.

Most microbe-derived marine natural products tend to be isolated from bacteria, which make up much of the biomass in seawater (i.e., $>10^{5}$ cells per milliliter) and are extremely well represented in deep oceanic "muds". However, fungi are also abundant, as $10^{3}$ to $10^{4}$ fungal cells are contained in a milliliter of seawater. Approximately $38 \%$ of the reported $\sim 23,000$ bioactive microbial metabolites are of fungal origin and only $5 \%$ of the microbial taxa had been identified as of 2008, 10\% of which are fungi [5]. Fungi have larger genomes with more BGCs, resulting in greater chemodiversity [6,7]. Furthermore, they have produced numerous clinically approved anti-infectives and antitumor drugs, as mentioned earlier, but remain understudied.

Why are there disparities in the isolation of marine natural products from fungi? While genetic engineering and 'omics methods are being used to isolate an increasing amount of bacterial natural products, these methods are still in their infancy insofar as fungi are concerned. Cultivation which is still one of the main ways to discover bioactive metabolites continues to be a challenge when working with marine fungi. Scientists are still using antiquated methods that promote the growth of generalist genera, such as Penicillium and Aspergillus to culture marine fungi [8]. In 2019, we published a compendium of bioactive compounds isolated from marine fungi [9]. Herein, we update that list, focusing on antiinfective and antitumor agents as well as other fungal natural products with potential from marine environments. This review aims to highlight the bioactive metabolites found from culturable fungi isolated from marine environments and cultivation methods that have been found to increase the production of diverse bioactive metabolites.

Although we are listing significant numbers of compounds (approximately 200) in this review, we will only show the structures of compounds for which biological activities have been reported and will give the names of the others with suitable references, so that readers may consult the original literature for related compounds without a biological activity reported at that time.

\subsection{Antitumor Agents from Deep-Sea Sediments}

It should be mentioned at this point that it was well known in the early days of antimicrobial assays, though never formally reported from the pharmaceutical industry, that compounds with antitumor activities in vitro also inhibited Gram-positive bacteria at comparable concentrations in disc diffusion assays (DJN Personal Observations). The following examples will be arranged as best we can, by the area(s) from which the sediments were collected for subsequent isolation of fungi. 


\subsection{Indian Ocean}

Numerous potential antitumor agents (some also with antibacterial activity) continue to be isolated and reported from deep-sea-derived fungi collected from the Indian Ocean. The new diterpenoids, longidiacids A (1) and B, polyketides, and the cytochalasin analogs, longichalasins A and B (2), were isolated from the fungus Diaporthe longicolla FS429 [10] obtained from deep-sea sediment collected at a depth of $3000 \mathrm{~m}$. Longidiacid A (1) and longichalasin B (2) inhibited tyrosine phosphatase B in Mycobacterium tuberculosis cells by $35.4 \%$ and $53.5 \%$, respectively, and longichalasin B (2) exhibited antiproliferative activity against glioblastoma cells (SF-268) with an IC $_{50}$ value of $16.44 \mu \mathrm{M}$.

From sediment collected at a depth of $3471 \mathrm{~m}$, the fungus Cladosporium cladosporiodes HDN14-342 yielded the polyketides, clindanones A and B as well as cladosporols F and G $(3,4)$ following cultivation [11]. Cladosporols $\mathrm{F}$ and $\mathrm{G}$ exhibited cytotoxic activities against the human cervical (HeLa), leukemia (K562), and colon (HCT-116) cancer cells with IC 50 values ranging from 3.9 to $23.0 \mu \mathrm{M}$ depending upon the particular cell line. In 2017, Li et al. published revisions of the initial structures of these two metabolites [12].

Phomopsis lithocarpus FS508 was isolated from a sediment sample collected at $3606 \mathrm{~m}$ and fermented, producing several benzophenone aldehydes, including tenellone $\mathrm{H}$ (5). This benzophenone exhibited cytotoxic activity against liver (HepG-2; $\mathrm{IC}_{50} 16 \mu \mathrm{M}$ ) and lung (A549; $\mathrm{IC}_{50} 17.6 \mu \mathrm{M}$ ) cancer cell lines [13]. At the even deeper depth of $5752 \mathrm{~m}$, the trimeric peniphenylanes $A$ and $B$ and dimeric peniphenylanes $C-G$ were reported from Penicillium fellutanum HDN14-323 isolated from that deep-sea sediment. Of these seven compounds, only peniphenylane $\mathrm{D}(\mathbf{6})$ exhibited reasonable cytotoxic activity against the cervical cancer cell $\left(\mathrm{HeLa} ; \mathrm{IC}_{50}=9.3 \mu \mathrm{M}\right)[14]$.

\subsection{Seas near China}

Moving further East, several cytotoxic agents have been reported from fungi from deep-sea sediment collected in the South China Sea. For example, the cytotoxic agent acaromycin A (7) along with acaromyester A were isolated from Acaromyces ingoilii FS121 collected from deep-sea sediment at a depth of $3415 \mathrm{~m}$. The naptha-[2,3-b] pyrandione analog acaromycin A (7) exhibited cytotoxic activities against human breast (MCF-7), brain (SF-268), liver (HepG-2), and lung (NCI-H460) cancer cells with $\mathrm{IC}_{50}$ values less than $10 \mu \mathrm{M}[15]$.

At a deeper depth of $3739 \mathrm{~m}$, engyodontiumones A-J and 2-methoxyl-cordyol C were isolated from Engyodontium album DFFSCS02. Engyodontiumone H (8) exhibited cytotoxic activity against human histiocytic lymphoma U937 cells $\left(\mathrm{IC}_{50}=4.9 \mu \mathrm{M}\right)$ together with antibacterial activity against Escherichia coli and Bacillus subtilis at a concentration of $25 \mu \mathrm{g} /$ disc (which is low activity for a disc diffusion assay). Engyodontiumin A (9), isolated from the same fungus, exhibited antimicrobial activities against Aspergillus niger, multidrugresistant Staphylococcus aureus, Vibrio vulnificus, V. rotiferianus, and V. campbellii [16].

\subsection{Eastern Pacific Ocean}

Several new breviane spiroditerpenoids, breviones F-I, were isolated from a deep ocean sediment-derived Penicillium sp. (MCCC 3A00005) collected in the East Pacific Ocean at a depth of $5115 \mathrm{~m}$ [17]. Brevione F (10) inhibited HIV-1 replication in C8166 cells with an $\mathrm{EC}_{50}$ value of $14.7 \mu \mathrm{M}$. Breviones $\mathrm{F}-\mathrm{H}(\mathbf{1 0}-\mathbf{1 2})$ exhibited minimal cytotoxic activity against HeLa cells ( 25 to $50 \%$ growth inhibition at $10 \mu \mathrm{g} / \mathrm{mL}$ ). Finally, from these agents, brevione I (13) was cytotoxic against the breast cancer line MCF-7 $\left(\mathrm{IC}_{50}=7.44 \mu \mathrm{M}\right)$ but barely active against the lung cancer $\mathrm{A} 549$ cell line $\left(\mathrm{IC}_{50}=32.5 \mu \mathrm{M}\right)$ [18].

A series of sorbicillinoid derivatives, trisorbicillinone A-D, oxosorbiquinol, dihydrooxosorbiquinol, dihydrodemethylsorbicillin, dihydrotrichodermolide, and phialofurone, were isolated from the deep ocean fungus Phialocephala sp. Fl30 $\mathrm{r}$ collected from sediment at $5059 \mathrm{~m}$ in the East Pacific Ocean [19-21]. Of these agents, only trisorbicillinone A (14) exhibited any significant cytotoxic activity against the HL60 tumor cell line $\left(\mathrm{IC}_{50}=3.14 \mu \mathrm{M}\right)$ [19]. Oxosorbiquinol (15) and its dihydro derivative (16) were marginally to effectively inactive 
as cytotoxins against the following tumor cell lines; leukemia (P388, HL60, and K562) and the hepatocellular BEL7402 cell lines with $\mathrm{IC}_{50}$ values from 8.9 to $68.2 \mu \mathrm{M}$, respectively [19]. By contrast, dihydrodemethylsorbicillin (17), dihydrotrichodermolide (18), and phialofurone (19, Figure 1) exhibited cytotoxic activity against the leukemia cell lines (P388 and $\mathrm{K} 562$ ) with $\mathrm{IC}_{50}$ values ranging from 0.1 to $22.9 \mu \mathrm{M}$ [21].
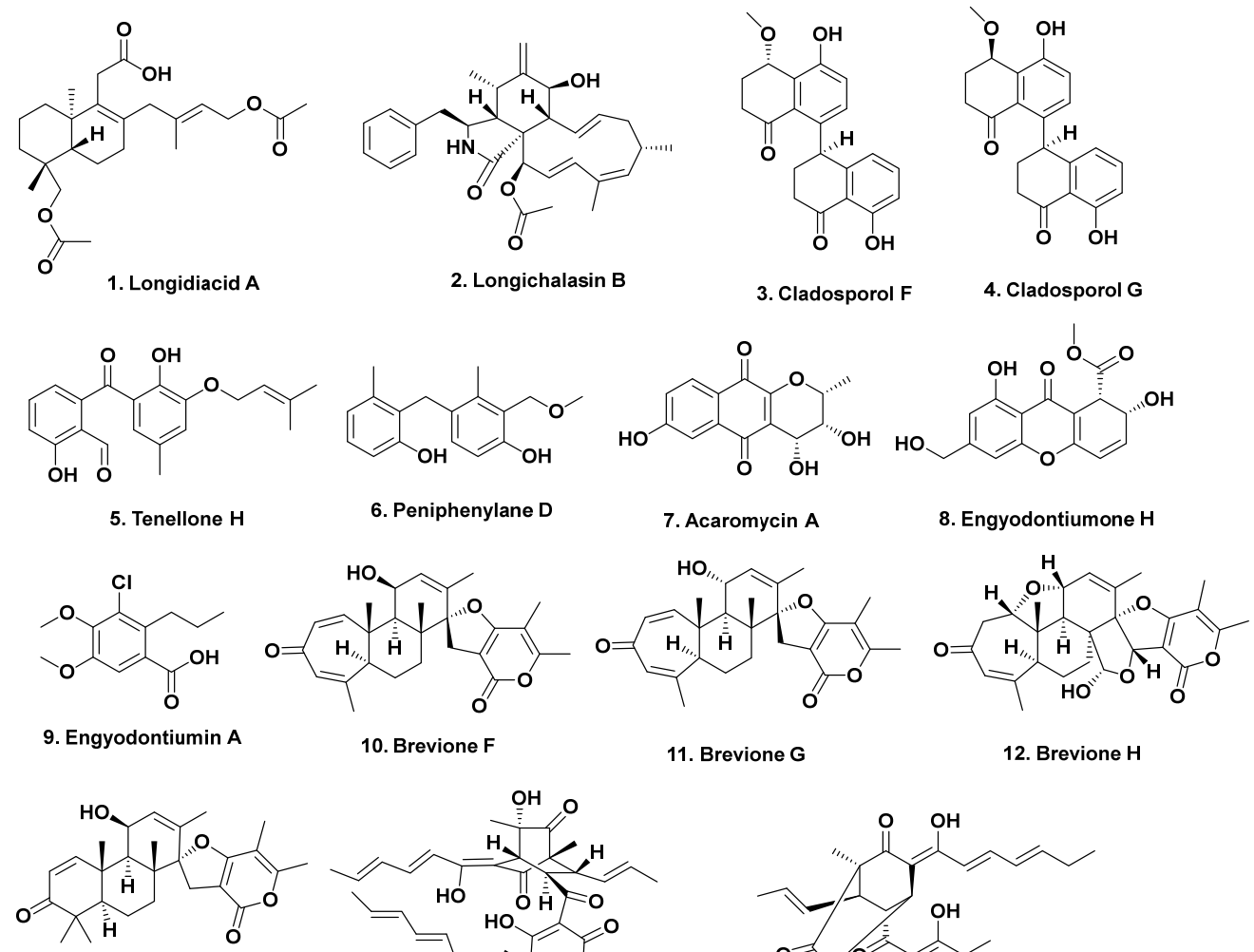

10. Brevione F

11. Brevione G

12. Brevione $\mathrm{H}$
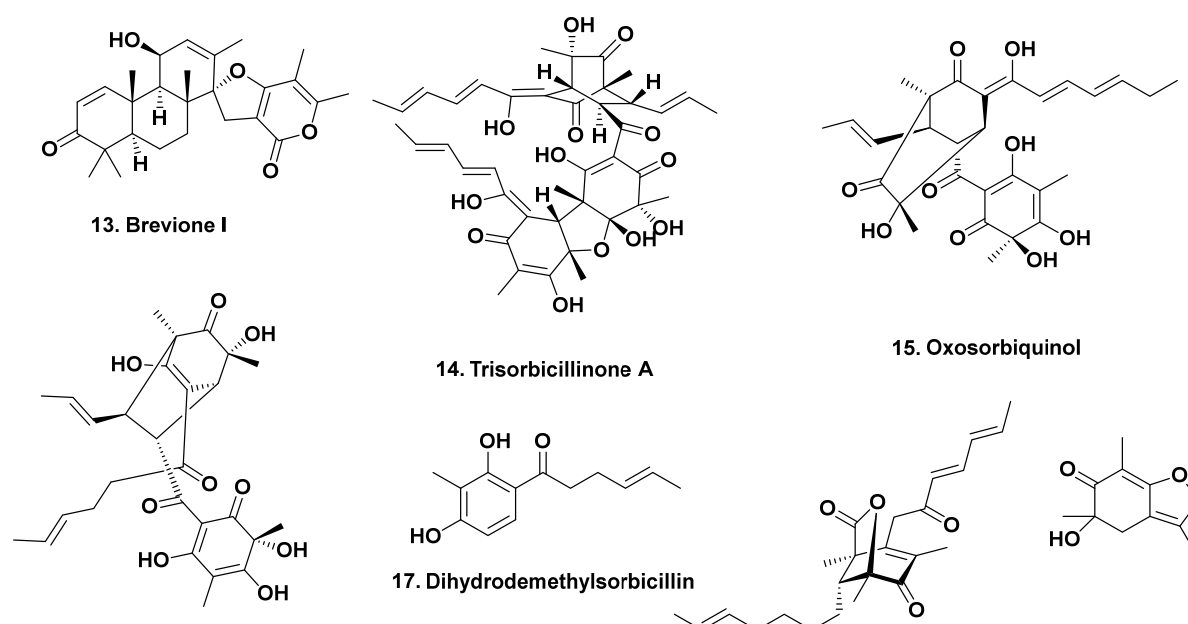

14. Trisorbicillinone $A$

15. Oxosorbiquinol

16. Dihydrooxosorbiquinol

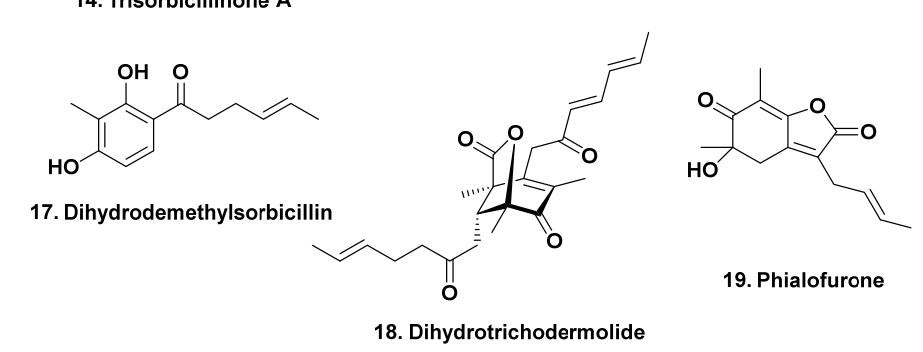

Figure 1. Antitumor Active Agents \{Multiple Ocean Areas\} (Structures 1 to 19).

\section{Anti-Infective Agents from Deep-Sea Fungi}

\subsection{South Atlantic Ocean}

Marine fungi are also abundant sources of anti-infectives, including potential antifungal, antibacterial, antiprotozoal, and antiviral agents. For example, 19 thiodiketopiperazine alkaloids, eutypellazines A-S, were isolated from the marine-derived fungus Eutypella sp. MCCC 3A00281 collected at a depth of $5610 \mathrm{~m}$ in the South Atlantic Ocean [22,23]. Eutypellazines A-L (20-31) exhibited anti-HIV activity against pNL4.3Env-Luc co-transfected $293 \mathrm{~T}$ cells with $\mathrm{IC}_{50}$ values ranging from 3.2 to $18.2 \mu \mathrm{M}$. Eutypellazines P-S (32-35, Figure 2) inhibited the growth of S. aureus ATCC 25923 and vancomycin-resistant Enterococci with MIC values ranging from 16 to $32 \mu \mathrm{M}[22,23]$. 


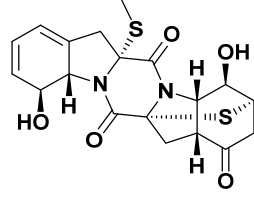

20. Eutypellazine A

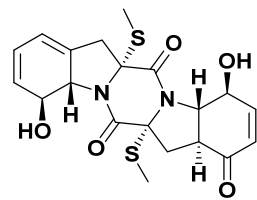

24. Eutypellazine E

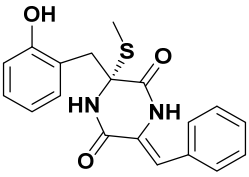

28. Eutypellazine I

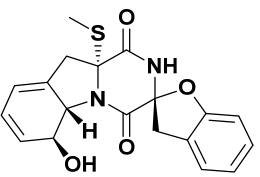

32. Eutypellazine $P$

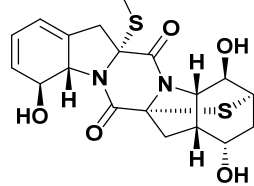

21. Eutypellazine B

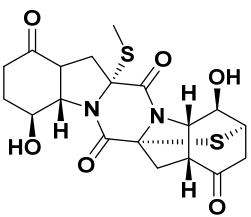

25. Eutypellazine $F$

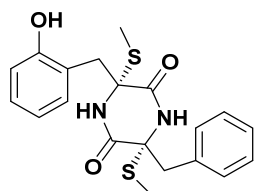

29. Eutypellazine J

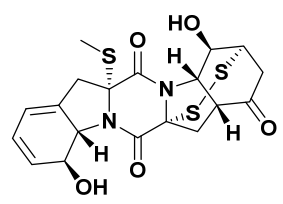

33. Eutypellazine $Q$

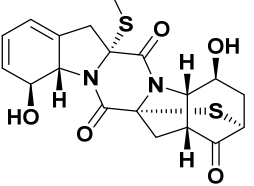

22. Eutypellazine $\mathrm{C}$

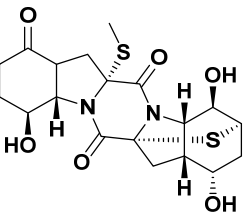

26. Eutypellazine $G$

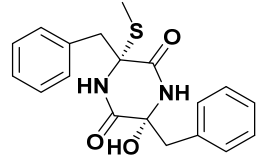

30. Eutypellazine $K$

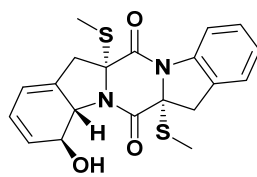

34. Eutypellazine $R$

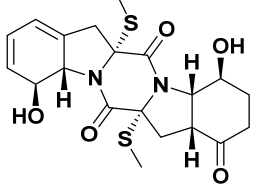

23. Eutypellazine $D$

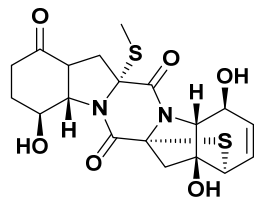

27. Eutypellazine H

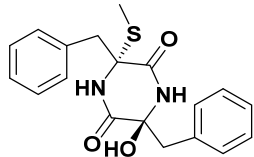

31. Eutypellazine L

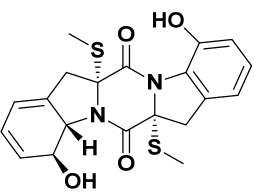

35. Eutypellazine $S$

Figure 2. Anti-HIV and Antibacterial Active Agents \{South Atlantic Ocean, South China Sea, Indian and West Pacific Oceans\} (Structures 20 to 35).

\subsection{South China Sea}

The alkaloids arthpyrones D-K were isolated from Arthrinium sp. UJNMF0008 collected from the South China Sea at a depth of $3858 \mathrm{~m}$. Of these eight, four, arthpyrones F-I (36-39), exhibited antibacterial activity against Mycobacterium smegmatis and S. aureus with $\mathrm{IC}_{50}$ values ranging from 1.66 to $42.8 \mu \mathrm{M}$ [24]. From the deep-sea fungus, P. brevicompactum DFFSCS025, isolated from sediment collected at $3928 \mathrm{~m}$ depth in the South China Sea, two alkaloids, breviamides $X$ and $Y$, and two mycochromenic acid derivatives, 6-(methyl 3-methylbutanoate)-7-hydroxy-5-methoxy-4-methylphthalan-1-one

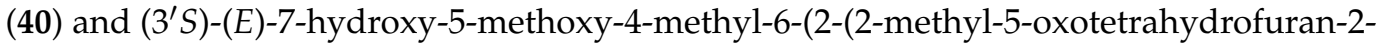
yl)vinyl) isobenzofuran- $1(3 \mathrm{H})$-one, were purified. Of these four, only compound 40 exhibited significant antifouling activity against the bryozoan Bugula neritina with an $\mathrm{EC}_{50}$ value of $13.7 \mu \mathrm{M}$ and an $\mathrm{LC}_{50} / \mathrm{EC}_{50}$ value > 100 [25].

A small series of compounds were isolated from fermentation of the fungus Emericella sp. SCSIO 05240, collected from sediment at a depth of $3258 \mathrm{~m}$ in the South China sea. These were four new prenylxanthones, named as emerixanthones A-D. These four agents structurally differ by chlorination, methylation, and hydroxylation, and of the four congeners, two, emerixanthones A (41) and C (42), exhibited weak antibacterial activity against several bacterial pathogens, including E. coli, Klebsiella pneumonia, S. aureus, E. faecalis, Acinetobacter baumanni, and Aeromonas hydrophilia. Interestingly, one of the remaining two compounds, emerixanthone D (43), exhibited mild antifungal activity against several agricultural pathogens, including Fusarium sp., Penicillium sp., A. niger, Rhizoctonia solani, Fusarium oxysporium f. sp. niveum, and F. oxysporium f. sp. cucumeris [26]. 


\subsection{Indian Ocean}

From sediment collected in the Indian Ocean at a depth of $3972 \mathrm{~m}$, the versicoloids $\mathrm{A}$ and $\mathrm{B}$ as well as two 4-aryl-quinolin-2-one alkaloids and prenylated xanthones, versicones $\mathrm{A}-\mathrm{D}$, were isolated from culturing the fungus $A$. versicolor SCSIO 05879 . Of these four compounds, only versicoloids $A$ and $B(44,45)$ demonstrated activity against the plant pathogen Colletotrichum acutatum (MIC $1.6 \mu \mathrm{g} / \mathrm{mL}$ ) [27].

\subsection{West Pacific Ocean}

From sediment collected at a depth of $2869 \mathrm{~m}$ in the West Pacific Ocean, the fungus $A$. versicolor was isolated and upon fermentation produced the anthraquinone antimicrobial agent 2-(dimethoxymethyl)-1-hydroxyanthracene-9,10-dione (46, Figure 3). This compound exhibited antibacterial activity against multidrug-resistant strains of $S$. aureus ATCC 43300 (MIC $3.9 \mu \mathrm{g} / \mathrm{mL}$ ) and CGMCC 1.12409 (MIC $7.8 \mu \mathrm{g} / \mathrm{mL}$ ). In addition, it was also weakly active against strains of Vibrio (MICs of 15.6-62.5 $\mathrm{gg} / \mathrm{mL}$ ). Molecular docking studies with topoisomerase IV and AmpC $\beta$-lactamase further supported its antibacterial properties [28].

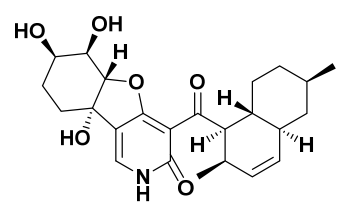

36. Arthpyrone F

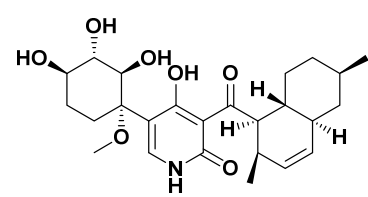

39. Arthpyrone I

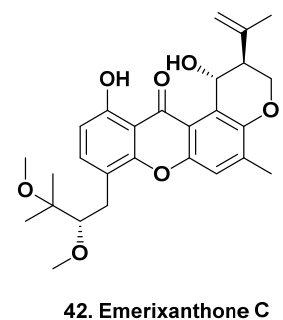

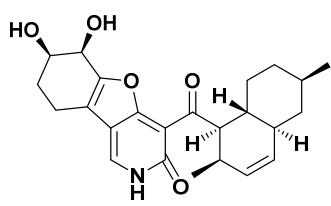

37. Arthpyrone G<smiles>COC(=O)C(C)CCc1c(O)c2c(c(C)c1OCC(C)C)COC2=O</smiles>

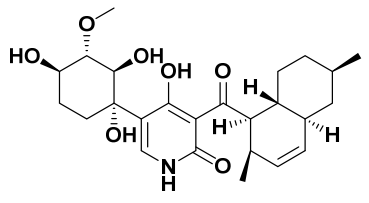

38. Arthpyrone $\mathrm{H}$<smiles>C=C(C)[C@@H]1COc2c(C)cc3oc4c(CCC(C)(C)Cl)ccc(O)c4c(=O)c3c2[C@H]1O</smiles>

ŌH<smiles>C=C(C)[C@@H]1COc2c(C)cc3oc4c(C[C@H](OC(C)=O)C(C)(C)O)ccc(O)c4c(=O)c3c2[C@H]1O</smiles><smiles>[R]C1(C(C)CC)NC(=O)[C@@H](C(C)C)n2c1nc1c(c2=O)C=C(OC)C=CO1</smiles>

44. Versicoloid $A ; R=H$ 45. Versicolloid $B ; R=O H$<smiles>COC(OC)c1ccc2c(c1O)C(=O)c1ccccc1C2=O</smiles>

46. 2-(dimethoxymethyl)-1-hydroxyanthracene-9,10-dione

Figure 3. Biologically Active Agents, Indian and West Pacific Ocean (Structures 36 to 46).

\section{Other Biologically Active Agents from Deep-Sea Fungi}

\section{1. (Probably) South China Sea}

Anti-inflammatory agents have also been isolated from extremophilic marine fungi. For example, the diketopiperazine alkaloids brevicompanines D-H were isolated from a deep ocean-sediment isolate of Penicillium sp. collected at a depth of $5080 \mathrm{~m}$. Of these five compounds, only brevicompanines E (47) and H (48) inhibited lipopolysaccharide-induced nitrous oxide production in microglial cells [29]. 


\subsection{Antarctica}

Another strain of Penicillium, P. granulatum MCCC 3A00475, isolated from deep-sea sediment collected at a depth of $2284 \mathrm{~m}$ from Prydz Bay in Antarctica yielded the antiallergic spirotetracyclic diterpene, spirograterpene A (49, Figure 4). This compound demonstrated a weak antiallergic activity on immunoglobulin E-mediated rat mast RBL-2H3 cells [30].

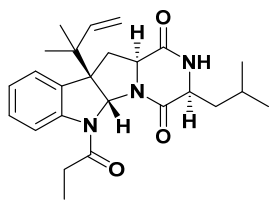

47, Brevicompanine E

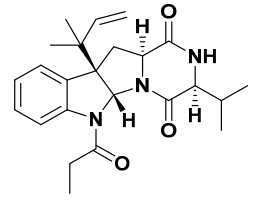

48. Brevicompanine $\mathrm{H}$

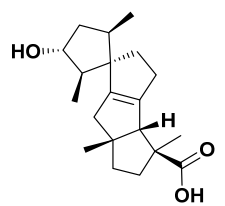

49. Spirograterpene $A$

Figure 4. Biologically Active Agents \{probably) South China Sea and Antarctica\} (Structures 47 to 49).

\section{Bioactive Compounds from Fungal Endophytes of Mangroves}

Marine fungi are often involved in mutualistic interactions, as their survival may well require relationships including symbiosis with other organisms. Many endophytic fungi have been isolated from mangroves, which are intertidal wetland environments comprising closely associated plants, animals, and microbes from many genera. These environments line (sub)tropical habitats, comprising one-quarter of the tropical coastline in the world (over 15.5 million hectares) [31].

Mangroves are frontiers between land and sea, a mixture of freshwater and saltwater, exporting plant detritus and faunal biomass to support life offshore. Currently, the Bandaranayake paper [31] has been cited over 350 times, demonstrating the "ecological value" of these marine/freshwater environments. These environments are complex and rich in fungal species diversity, largely based on the availability of colonizable substrata. Within these environments, fungi play an important role in the nutrient cycles, transforming polymeric substances into smaller and simpler organic matter that can be used by other organisms [32]. These secondary metabolic products help organisms cope with biotic stress factors, such as varying water and salt levels. There is also intense competition for space; thus, secondary metabolites are used as a form of chemical defense and/or offense to combat pathogens, herbivores, and other organisms.

Two recent reviews on anti-infectives from mangrove endophytic fungi were published by Deshmukh et al. in 2020 [33] and Cadamuro et al. in 2021 [34]. Many of these fungi have been reported from China, primarily due to their research groups now studying mangrove endophytes instead of their medicinal plant hosts [35]. These fungi typically belong to the genera Aspergillus, Phomopsis, Pestalotiopsis, and Penicillium, which is not surprising due to the cosmopolitan nature of these genera. The Chinese have a longstanding history of using traditional herbal mixtures to treat disease and have known about the toxic properties of marine natural products for centuries. However, many of these newly isolated compounds have been published in local journals or those dedicated to plant research, such as Phytochemistry, Planta Medica, Phytomedicine, or Phytochemical letters, and thus were not frequently read/cited by scientists involved in marine chemistry.

The She group at Sun Yat-Sen University has focused on identifying bioactive metabolites from mangrove-derived endophytic fungi from the South China Sea. Many of these metabolites have been published in Phytochemical Letters, Planta Medica, as well as Marine Drugs. For example, in 2014, Liu and coworkers published a paper in Planta Medica on three new vermistatin derivatives produced by a mangrove endophytic Penicillium sp. HN29-3B1 isolated from the sea mango Cerbera manghas in the South China Sea. With the exception of $5^{\prime}$-hydroxypenisimplicissin, both 6-demethylpenisimplicissin (50) and $2^{\prime}$-epihydroxydihydro-vermistatin (51) exhibited $\alpha$-glucosidase inhibitory activity with $\mathrm{IC}_{50}$ values of 9.5 and $8.0 \mu \mathrm{M}$, respectively [36]. A year later, this group reported the production of pinazaphilones $\mathrm{A}$ and $\mathrm{B}, 4^{\prime}$-(S)-(3,5-dihydroxyphenyl)-4'-hydroxy-6'-methylcyclopent$1^{\prime}$-en-5'-one, $6^{\prime}$-methyl-[1,1'-biphenyl]-3,3', $4^{\prime}, 5$-tetraol, and penicidone $\mathrm{D}$ from the same 
fungal isolate. Pinazaphilone B (52) and $6^{\prime}$-methyl-[1,1'-biphenyl]-3, $3^{\prime}, 4^{\prime}, 5$-tetraol (53) inhibited $\alpha$-glucosidase with $\mathrm{IC}_{50}$ values of 28.0 and $2.2 \mu \mathrm{M}$, respectively, demonstrating their potential as antidiabetic agents [37].

The She group has reported several metabolites produced by endophytic Talaromyces. In 2011, they reported cytotoxic norsesquiterpene peroxides produced by an endophytic T. flavus isolated from the leaves of the mangrove plant Sonneratia apetala collected along the saltmarsh of the South China Sea [38]. Talaperoxides A to D (54-57), constituted two isomeric pairs exhibiting toxicity to brine shrimp at median lethal doses $\left(\mathrm{LD}_{50}\right)$ of less than $10 \mathrm{ppm}$. These compounds were also evaluated for cytotoxicity against human breast (MCF-7 and MDA-MB-435), hepatoma (HepG2), cervical (HeLa), and prostate (PC-3) cancer cell lines. Talaperoxides B (55) and D (57) were cytotoxic against these cell lines with $\mathrm{IC}_{50}$ values ranging from 0.89 to $1.92 \mu \mathrm{g} / \mathrm{mL}$. The group later reported two new benzophenone derivatives, peniphenone and methylpeniphenone, from the mycelia of an endophytic Penicillium sp. ZJ-SY2 isolated from the same plant [39]. Peniphenone (58) exhibited immunosuppressive activity against T-cell (concanavalin A-induced) and B-cell (liposaccharide-induced) proliferation in mouse splenic lymphocytes with $\mathrm{IC}_{50}$ values of 8.1 and $9.3 \mu \mathrm{g} / \mathrm{mL}$, respectively. The methyl ester methylpeniphenone (59) exhibited weaker activity against $\mathrm{T}$ cells and B cells with $\mathrm{IC}_{50}$ values of 17.5 and $23.7 \mu \mathrm{g} / \mathrm{mL}$, respectively. More recently, the group reported two new depsidones, talaromyones A and B, produced by cultures of Talaromyces stipitatus SK-4 isolated from the leaves of the mangrove plant Acanthus ilicifolius from the Shankou Mangrove Nature Reserve in China. The acetylated depsidone talaromyone B (60) exhibited antibacterial activity against $B$. subtilis $(\mathrm{MIC}=12.5 \mu \mathrm{g} / \mathrm{mL})$ as well as $\alpha$-glucosidase activity $\left(\mathrm{IC}_{50}=48.4 \mu \mathrm{M}\right)[40]$.

Over the last decade, reports on the number of mangrove-derived strains of Talaromyces that produce bioactive metabolites have increased, especially as taxonomic revisions have been made to species with symmetrical biverticillate conidiophores. For more information on secondary metabolites from mangrove-associated strains of Talaromyces, the 2018 review by Nicoletti et al. in Marine Drugs is an excellent source of information [41].

Other research groups have reported bioactive compounds from fungal endophytes isolated from mangrove-associated medicinal plants. For example, Lin and coworkers published a paper in Phytochemistry describing four new polyketides produced by endophytic Penicillium sp. JP-1 isolated from the inner bark of Aegiceras corniculatum collected in Fujian, China [42]. A. corniculatum is a shrub known for its analgesic, cytotoxic, and antidiabetic properties $[43,44]$. Leptosphaerone $C$, penicillenone, arugosin I, and 9-demethyl FR-901235 isolated from fungal endophytes of this plant were evaluated for cytotoxic activity against human lung cancer (A-549) and murine lymphocytic leukemia (P388) cell lines. Leptosphaerone $C(\mathbf{6 1})$ exhibited cytotoxic activity against human lung cancer cells (A-549; $\mathrm{IC}_{50} 1.45 \mu \mathrm{M}$ ) while penicillenone (62) was cytotoxic against murine lymphocytic leukemia $\left(\mathrm{P} 388 ; \mathrm{IC}_{50}=1.38 \mu \mathrm{M}\right)$.

In 2012, the Wang group published a communication reporting a new cytotoxic and antifungal metabolite, chaetoglobosin $X$ (63) from an endophytic fungus isolated from the leaves of Curcuma wenyujin Y.H. Chen et C. Ling, which belongs to the ginger family, collected in Zhejiang Province, Wenzhou, China [45]. Chaetoglobosin X (63) exhibited antifungal activity against several plant pathogens, including Exerohilum turcicum, F. oxysporum f. sp. Cucumerinim, Curoularia lunata (MIC; $3.125 \mu \mathrm{g} / \mathrm{mL}$ ), as well as F. graminearum and F. moniliforme (MIC; $6.25 \mu \mathrm{g} / \mathrm{mL}$ ). Other chaetoglobosins have been reported from the mangrove endophytic fungus P. chrysogenum V11 isolated from the vein of the medicinal plant Myoporum bonitioides A. Gray in the Leizhou Penninsula in China [46]. These included penochalasin I (64), containing an unprecedented six-membered fused ring system, and penochalasin J (65). Penochalasin I (65) exhibited cytotoxic activity against gastric (SGC-7901) and breast cancer cell lines (MDA-MB-435) with IC 50 values below $10 \mu \mathrm{M}$. Penochalasin J (65) exhibited antifungal activity against the plant pathogen Colletotrichum gloeosporioides with an MIC of $25.08 \mu \mathrm{M}$, which was more active than the known antifungal agent carbendazim. Other antifungal 
agents have been reported from endophytic fungi from this plant. These agents can be found in the following reports by Li et al. [47-49].

\section{Preclinical and Clinical Trials of Mangrove Endophytic-Sourced Compounds}

Secondary metabolites isolated from mangrove fungi have entered preclinical and clinical trials. One metabolite was isolated along with a number of cytotoxic anthracenedione derivatives from the mangrove endophytic fungus Halorosellina sp. no 1403 collected from the South China Sea. This compound, the anthroquinone SZ-685C (66), was reported by the She group and demonstrated in vitro and in vivo cytotoxic activity [50]. This agent is structurally similar to the clinically used anticancer drug epiadriamycin and exhibited cytotoxic activity against human breast cancer (MCF-7, IC I0 $_{5} 7.5 \mu \mathrm{M}$; MDA-MB-435, IC $503.0 \mu \mathrm{M}$ ), prostate cancer (PC-3 cell line, $\mathrm{IC}_{50} 4.1 \mu \mathrm{M}$ ), glioblastoma (LN-444, $\mathrm{IC}_{50} 7.8 \mu \mathrm{M}$ ), and hepatoma $\left(\mathrm{Hep}-3 \mathrm{~B}, \mathrm{IC}_{50}=3.2 \mu \mathrm{M}\right.$; Huh-7, $\left.\mathrm{IC}_{50}=9.6 \mu \mathrm{M}\right)$ cell lines. Importantly, SZ-685C (66) exhibited low cytotoxic activity against healthy epithelial cells [50], and increased sensitivity towards the invasive and estrogen-independent breast cancer cell lines, which are more resistant to anti-estrogen therapy. Thus, SZ-685C (66) may be a promising treatment for adriamycin-resistant breast cancer, and a patent was filed in 2010 [51]. Xenograft studies in which mice inoculated with MDA-MB-435 cells were dosed with $50 \mathrm{mg} / \mathrm{kg}$ of SZ-685C (66) showed a significant decrease of $61 \%$ in tumor volume after 35 days of drug administration. SZ-685C (66) was later found to selectively induce apoptosis in malignant cells in vitro and in vivo via the inhibition of the Akt pathway, which helps cancer cells survive apoptosis [52].

Additional in vitro assays and mechanistic studies have been published on SZ-685C (66). In 2013, Chen and coworkers reported inhibition of pituitary adenoma, specifically rat prolactinoma (MMQ) cells, and normal rat pituitary cells (RPCs) with $\mathrm{IC}_{50}$ values of $13.2 \mathrm{mM}$ and $49.1 \mathrm{mM}$, respectively [53]. The apoptotic activity of SZ-685C in the pituitary adenoma cells resulted from the downregulation of miR-200c, a microRNA implicated in regulating tumorigenesis and commonly upregulated in various tumors. It also inhibited MMQ cells, lowering their miR-200c levels in a dose-dependent manner and exhibited less toxicity toward RPCs. SZ-685C (66) was also reported to inhibit human nasopharyngeal carcinoma $\left(\mathrm{CNE} 2 ; \mathrm{IC}_{50}=8.97 \mu \mathrm{M}\right)$ and its radioresistant analog $\left(\mathrm{CNE} 2 \mathrm{R} ; \mathrm{IC}_{50}=8.94 \mu \mathrm{M}\right)$ cell lines after only $72 \mathrm{~h}$ of treatment [54]. In 2015, SZ-685C (66) was also reported to exhibit cytotoxic activity against non-functioning pituitary adenoma, a benign growth, by upregulating caspase- 3 and phosphate and tensin (PTEN) homolog and decreasing Akt expression levels [55]. The lack of selectivity between CNE2 and CNE2R is notable, as radioresistance is a major challenge for naso-pharyngeal carcinoma patients and has been linked to the activation of several pro-apoptotic signaling pathways. Significant decreases in miR-205 expression levels were observed in CNE2R cells incubated with SZ-685C (66), inactivating the miR-205-PTEN-Akt and Stat3-Jab1-p27 pathways. Thus, SZ-685C (66) could also be a promising treatment for nasopharyngeal carcinoma patients. To date, there have been no additional reports on (pre)-clinical studies on this compound.

\section{Plinabulin Clinical Trials}

Aside from SZ-685C (66), the only other marine-derived fungal metabolite in the clinical trials pipeline is the cytotoxic agent plinabulin (NPI-2358; 67), a synthetic derivative of the diketopiperazine halimide (68). Halimide (68) is produced by Aspergillus sp. CNC139 isolated from the green alga Halimeda copiosa collected from the coast of the Philippine Islands as part of studies funded under an NIH Cooperative grant system known as the NCDDG (National Cooperative Drug Discovery Group). These grants involved both academia and the pharmaceutical industry, with in this case, NIH/NCI involvement. The NCDDG consortium that discovered halimide (68) was led by the Fenical group at the Scripps Oceanographic Institution in La Jolla California, with a report covering their initial results published in 2000 [56]. Fenical and Jensen set up the small company Nereus to further develop agents from the NCDDG and other microbial sources. Some of the earlier 
work that led to the identification of plinabulin (67) can be found in the 2006 review by Gullo et al. [57]. In combination with docetaxel, plinabulin (67) has been used to treat nonsmall-cell lung cancer patients in Phase III clinical trials, where it had extended long-term survival and reduced neutropenia side effects [58].

BeyondSpringPharma who took over the compound following the dissolution of Nereus just (01DEC2021) received a complete response letter from the US FDA, requesting a second Phase III clinical trial for plinabulin (67). No comparable response from the China National Medical Products Administration has yet been published. Plinabulin (67, Figure 5) is also in Phase I and II trials to treat relapsed small-cell lung cancer patients and non-smallcell lung cancer patients with chemotherapy-induced neutropenia, respectively.

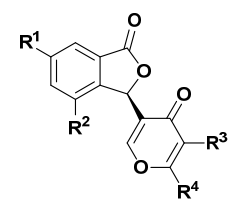

50. 6-Demethylpenisimplicissin $\mathbf{R}^{1}=\mathrm{OH}, \mathbf{R}^{2}=\mathrm{OCH}_{3}, \mathbf{R}^{3}=\mathrm{H}, \mathbf{R}^{4}=\mathrm{CH}_{3}$ 51. 2"-epihydroxydihydrovermistatin; $\mathbf{R}^{1}=\mathbf{R}^{2}=\mathrm{OCH}_{3}, \mathbf{R}^{3}=\mathrm{H}, \mathbf{R}^{4}=\mathrm{CH}_{2} \mathrm{CH}(\mathrm{OH}) \mathrm{CH}_{3}$

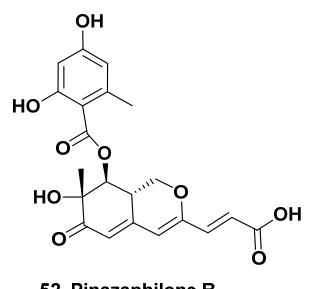

2. Pinazaphilone B<smiles>Cc1cc(O)c(O)cc1-c1cc(O)cc(O)c1</smiles><smiles>CC(=O)OC1C2CC34C(=O)CCC(C)(C)C3OOC14O2</smiles><smiles>CC(=O)OC1OOC23OC1CC2(C)C(C)(C)CCC3=O</smiles>
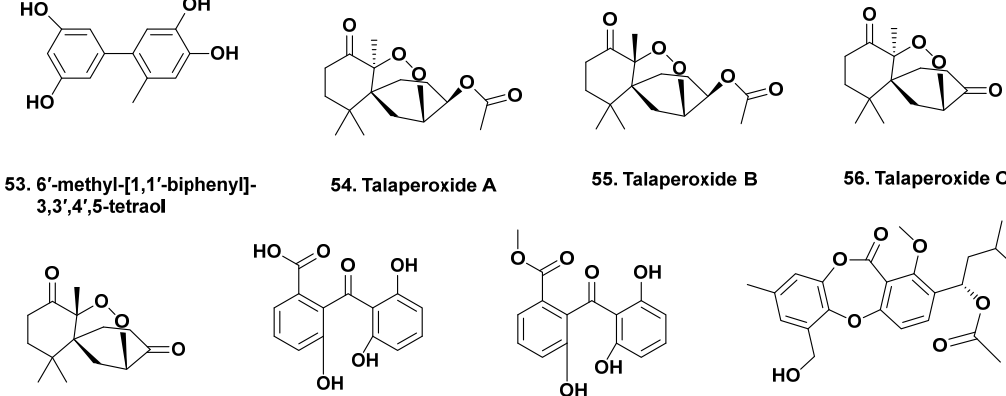

55. Talaperoxide B 6. Talaperoxide C

57. Talaperoxide D

58. Peniphenone

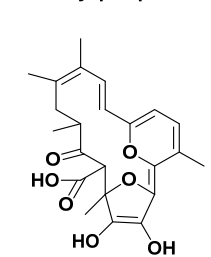

60. Talaromyone B<smiles>CC1=CC(=O)[C@H](O)[C@H](O)C1</smiles>

61. Leptosphaerne C<smiles>COc1ccc(/C(O)=C2/C(=O)[C@](C)(O)C(=O)C=C2C)c(O)c1</smiles>

62. Penicillenone
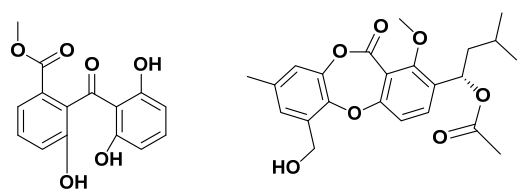

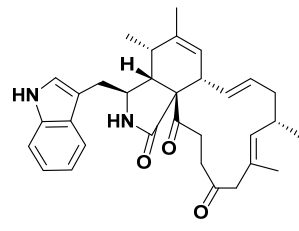

65. Penochalasin J<smiles>COc1cc(O)c2c(c1O)C(=O)C1=C(C2)C(O)C(O)C(C)(O)C1</smiles>

63. Chaetoglobosin $\mathrm{X}$

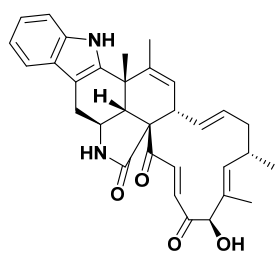

64. Penochalasin I

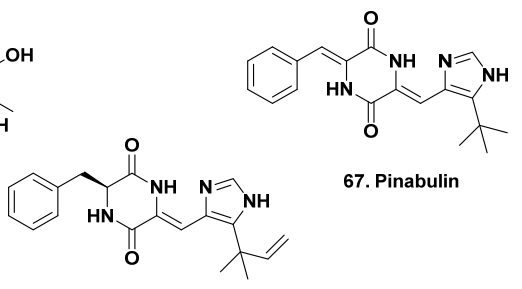

68. Halimide

Figure 5. Biologically Active Agents from Mangroves and Other Compounds in Clinical Trials (Structures 50 to 68 ).

\section{Bioactive Compounds from Fungi Isolated from Marine Vertebrates and Selected Invertebrates}

In addition to mangrove plants, marine fungi have mutualistic interactions with other organisms, including marine vertebrates, animals with backbones including fish, amphibians, mammals, reptiles, and birds. These animals have commensal, competitive, and predatory interactions with each other. For example, mammals find food by following birds and birds take advantage of the herding efforts of predatory fishes and mammals 
for food. Furthermore, these animals are active and mobile, covering wide distances to avoid competitors, reducing the rate of evolutionary divergence. Yet, their mobility also provides opportunities to obtain nutrients from different locations, increasing the diversity of their microbiomes.

From initial sequencing studies, the microbiomes of some mammals and marine vertebrates were found, as expected, to have gut microbiota diversity across species [59-62]. Several fish microbiomes have been sequenced and found to be unique environmental niches for the microbial production of new bioactive molecules [63]. While fish are the most dominant marine vertebrates, only a small number of natural products have so far been reported from these organisms. Fumiquinazolines A-G (69-75) were produced by the fungus $A$. fumigatus isolated from the gastrointestinal tract of the Japanese saltwater fish Pseudolabrus japonicas $[64,65]$. These peptidyl alkaloids have variable degrees of oxygenation, methylation, and substitution on their indole moieties and all exhibited cytotoxic activity against the murine lymphocytic leukemia (P388) cells with ED50 values of 6.1, 16.0, $14.6,17.7,52.0,13.5$ and $13.8 \mu \mathrm{g} / \mathrm{mL}$, respectively.

This next section might seem out of place, but we have put it here due to the similarity in the structures that were isolated, as this demonstrates that the "nominal host" is perhaps not the controlling factor. The structurally related fumiquinazolines $\mathrm{H}-\mathrm{L}$ were isolated from fermentation of an Acremonium sp. obtained from the non-vertebrate marine tunicate Ecteinascidia turbinata [66], as well as other marine-derived A. fumigatus and endophytic Scopulariopsis sp. isolated from non-vertebrate gorgonians [67]. Some of these fumiquinazolines inhibited the proliferation of mouse CDC2-mutant (tsFT210) cells, including compounds 69, 71, and 74 from the fish-related fungus and fumiquinazoline J (78, Figure 6) from the tunicate, while fumiquinazolines $\mathrm{H}-\mathrm{I}(\mathbf{7 6}, \mathbf{7 7})$ exhibited antifungal activity. The 2019 review by Resende et al. [68] is an excellent discussion on the fumiquinazolines, covering their source(s), chemical and biological activities. This review along with the 2020 article in Marine Drugs by Han et al. [69] should be consulted for current information on this class of fungal metabolites and relatives, including genomic aspects underlying their production.

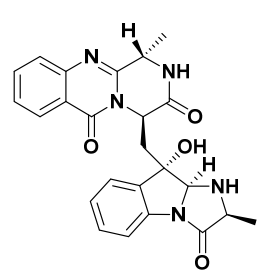

69. Fumiquinazoline $\mathrm{A}$

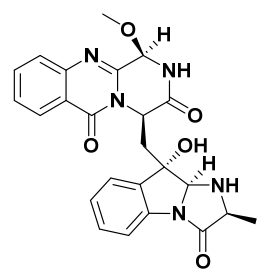

73. Fumiquiazoline $\mathrm{E}$

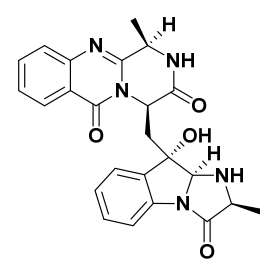

70. Fumiquinazoline $B$

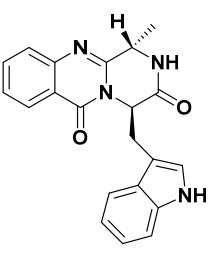

74. Fumiquiazoline $F$

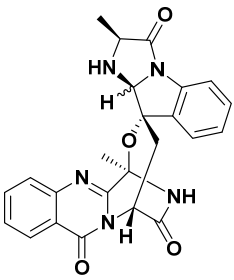

71. Fumiquinazoline $C$

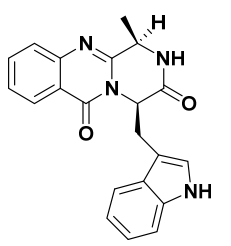

75. Fumiquiazoline G
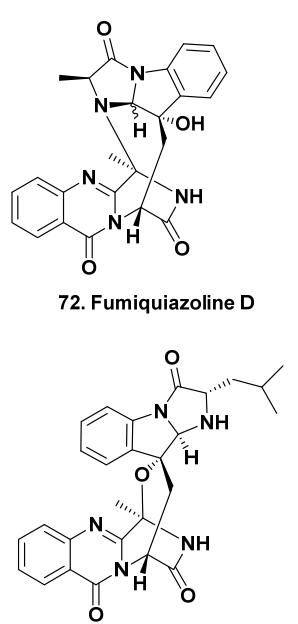

76. Fumiquiazoline $H$

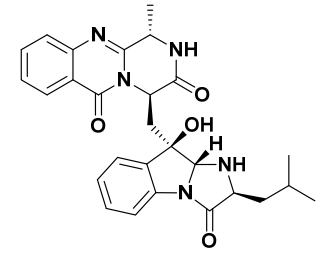

77. Fumiquinazoline I

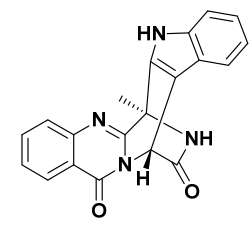

78. Fumiquinazoline $\mathrm{J}$

Figure 6. Bioactive Fumiquinazolines from Vertebrates and Invertebrates (Structures 69 to 78). 
Due to the duplication of structures and names related to fumiquinazolines published from different sources, with approximately 80 mentioned in the Resende et al. review [68], we have used the structures for fumiquinazoline A to J from that source, rather than those first reported in 1992 [64].

\section{Further Piscine-Sourced Agents}

A single fungal strain, Chaetomium globosum OUPS-T106B-6 isolated from the marine fish Mugil cephalus collected in Katsuura Bay, Japan led to the discovery of several cytotoxic polyketides. Two groups led by Tanaka $[70,71]$, reported six new cytotoxic azaphilones, the chaetomugilins A-F (79-84), that differed in their degrees of hydroxylation and methylation. All compounds exhibited cytotoxic activity against murine leukemia (P388) and human promyelocytic leukemia (HL-60) cell lines with $\mathrm{IC}_{50}$ values ranging from 1.3 to $18.7 \mu \mathrm{M}$. The bioactivity of chaetomugilins $C(\mathbf{8 1})$ and $F(84)$ indicate that the hydroxyl and methoxy groups at $\mathrm{C}-12$ and $\mathrm{C}-3^{\prime}$ contribute to their cytotoxicity. Furthermore, chaetomugilins A (79), C (81), and F (84) exhibited selective cytotoxic activity against 39 human cancer cell lines, implying that their modes of action were different from any other anticancer drug developed at the time of publication. Chaetomugilins $\mathrm{G}-\mathrm{H}$ (85-86), azaphilones with hydrolyzed lactone rings, were also reported by the authors from the same fungal strain [72]. Both compounds exhibited growth inhibitory activity against murine lymphocytic leukemia (P388 and L1210) as well as human promyelocytic leukemia (HL-60) and epidermoid carcinoma $(\mathrm{KB})$ cells with $\mathrm{IC}_{50}$ values ranging from reasonably active $(10.3 \mu \mathrm{M})$ to effectively inactive $(137.8 \mu \mathrm{M})$ for pure compounds.

The same research group later reported chaetomugilins I-O, which had either a fivemembered ether ring or various oxygenation and methylation patterns, from the same fungal strain [73]. Chaetomugilin I (87) also exhibited select cytotoxic activity against the same 39 human cancer cell lines mentioned above. Chaetomuglin J (88) was also recently reported to enhance apoptosis induced by cisplatin in human ovarian cancer cells, increasing their sensitivity to cisplatin by decreasing mitochondrial membrane potentials and increasing reactive oxygen species levels [74]. Derivatives in which the lactone moiety was hydrolyzed, seco-chaetomugilins A and D (89), were also found in the culture broth of the same fungal isolate [75]. The lack of the C-12 hydroxyl group in seco-chaetomugilin $\mathrm{D}$ possibly contributed to its weak cytotoxicity against the murine leukemias (P388 and L1210) as well as human leukemia and epidermoid carcinoma (KB) cell lines with values of 38.6, 53.6, 47.2, and $47.2 \mu \mathrm{M}$, respectively. Another weakly cytotoxic derivative, 11-epichaetomugilin A (90, Figure 7), was later reported by the same authors and it too, only exhibited weak cytotoxic inhibitory activity against murine lymphocytic leukemia (P388) and human promyelocytic leukemia (HL-60) cells with IC $_{50}$ values of 88.9 and $66.7 \mu \mathrm{M}$, respectively [76]. The chaetomugilin BGC has been characterized and should be further explored for new derivatives, as its structural scaffold appears to selectively target tumor cells and increase their sensitivity to other antitumor drugs [77].

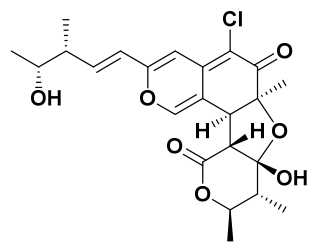

79. Chaetomugilin A

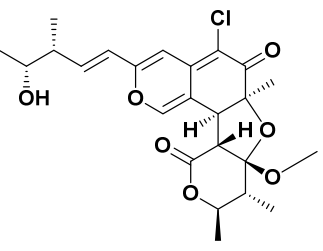

80. Chaetomugilin B

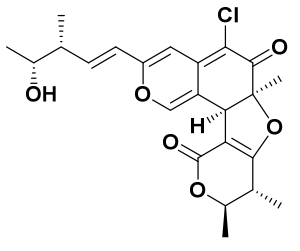

81. Chaetomugilin C

Figure 7. Cont. 


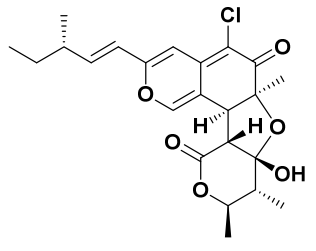

82. Chaetomugilin $D$

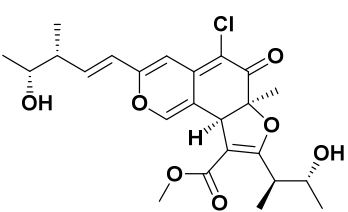

85. Chaetomugilin G

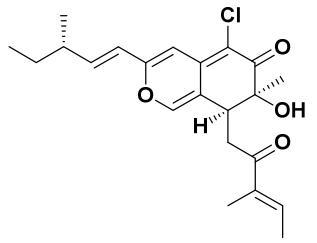

88. Chaetomugilin $\mathbf{J}$

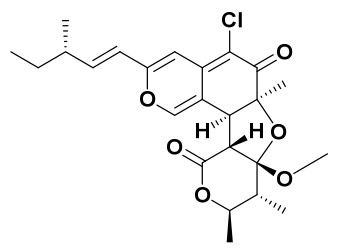

83. Chaetomugilin $E$

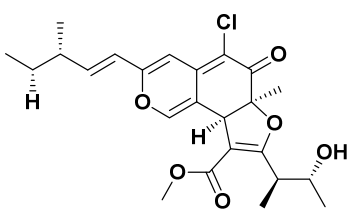

86. Chaetomugilin $\mathrm{H}$

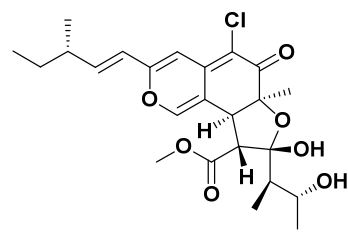

89. seco-Chaetomugilin D

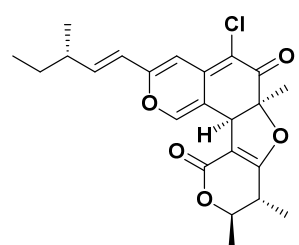

84. Chaetomugilin $F$<smiles>C/C=C(\C)C(=O)C[C@H]1C2=COC(/C=C/[C@@H](C)[C@H](C)O)=CC2=C(Cl)C(=O)[C@]1(C)O</smiles>

87. Chaetomugilin I

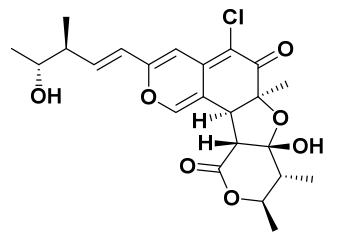

90. 11-Epichaetomugilin A

Figure 7. Bioactive Chaetomugulins and Derivatives from Piscine Sources (Structures 79 to 90).

\section{Bioactive Compounds from Fungi from Marine Invertebrates, Seagrass, Cyanobacteria and Algae}

The "nominal sources above" have been a rich source of bioactive fungal metabolites, especially because sponges are the most well-studied environment for bioactive agents and their "actual source(s)." Sponges usually have over 50\% of their mass composed of single-celled organisms which are the potential actual sources of the secondary metabolites isolated from the host invertebrate. Several cytotoxic metabolites have been reported from fungal strains isolated from sponges.

A new cyclohexapeptide (similanamide, 91) was isolated from cultures of the spongeassociated Aspergillus similanensis KUFA0013. The strain was isolated from the marine sponge Rhadbermia sp. collected from the coral reef of the Similan Islands in Thailand at a depth of $10 \mathrm{~m}$ [78]. Similanamide (91) exhibited weak activity against breast adenocarcinoma (MCF-7), non-small-cell lung cancer (NCI-H460), and melanoma cell lines with $\mathrm{GI}_{50}$ values ranging from 115 to $125 \mu \mathrm{g} / \mathrm{mL}$ [79]. In 2015, Masuda et al. [80] published a revision of the structure confirmed by total synthesis, identifying it as one of the two cyclic peptides reported in 2010 by Kai et al. Both peptides resulted from a cofermentation of the unidentified ascomycete OK-128 with okara, and exhibited paralytic activity against silkworms [81].

Seven new polyketides were isolated from Alternaria sp. SCIO41014 collected from the sponge Callyspongia sp. collected near Xuwen County, Guangdong Province, China. One of the isolated perylenequinone derivatives, 4,8,10-trihydroxy-1,2,11,12-tetrahydroperylene-3quinone (also named Altertoxin VII, 92), exhibited cytotoxic activity against a wide range of cancer cells, including human erythroleukemia (K562), human gastric carcinoma cells (SGC-7901), and hepatocellular carcinoma cells (BEL-7402) with $\mathrm{IC}_{50}$ values of $26.58 \pm 0.80$, $8.57 \pm 0.13$ and $13.11 \pm 0.95 \mathrm{ug} / \mathrm{mL}$, respectively [82].

New sorbicillinoid derivatives have been reported from a fungus isolated from the fresh internal tissue of a sponge collected from the South China Sea. Trichoreeseiones A-B, trichodermolide B, 13-hydroxy-trichodermolide, 24-hydroxy-trichodimerol (93), and 15-hydroxy-bisvertinol were isolated from Trichoderma reesei (HN-2016-018). Notably, 24-hydroxy-trichodimerol exhibited cytotoxic activity against lung (A549), breast (MCF-7), 
and liver (HCT-116) cancer cell lines with $\mathrm{IC}_{50}$ values of 5.1, 9.5, and $13.7 \mu \mathrm{M}$, respectively [83].

Crabs and sea cucumbers have also been a source of bioactive fungal secondary metabolites. The cyclic depsipeptides clavatustides A-B (94-95) were isolated from Aspergillus clavatus C2WU isolated from the crab Xenograpsus testudinatus from the hydrothermal vent Kueishantao in Taiwan [84]. Both compounds inhibited HepG2 liver cancer cell growth in the G1/S phase transition. An antimicrobial agent, cladomarine (96), was isolated from a sea-cucumber-derived fungus Penicillium coralligerum YK-247 collected at a depth of $3064 \mathrm{~m}$ on the Sao Paulo Plateau off the coast of Brazil. Cladomarine (96, Figure 8) exhibited antimicrobial activity in disc diffusion assays against the pathogens Saprolegnia parasitica and Pythium sp. sakari1 at a concentration of $10 \mu \mathrm{g}$ per disc [85].<smiles>CC(C)CC(NC(=O)[C@H](C)NC(=O)C(CC(C)C)N(C)C(=O)C1CCCCN1C(=O)c1ccccc1NC(=O)C(C)C)C(=O)NC(C)C</smiles>

91. Similanamide/PF1171C<smiles></smiles>

92. Altertoxin VII

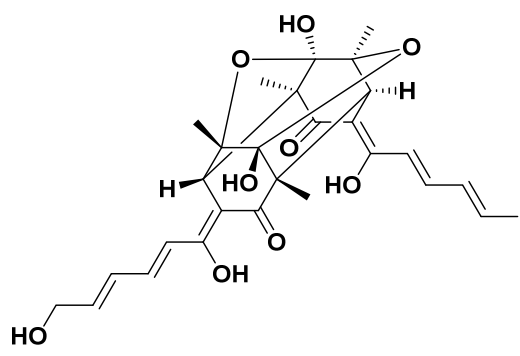

93. 24-Hydroxy-trichodimerol<smiles>CCN(CC(=O)Nc1ccccc1C(=O)Nc1ccccc1C(=O)O)C(=O)O[C@H](Cc1ccccc1)C(=O)O</smiles>

94. Clavatustide A

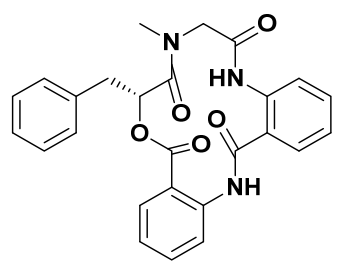

95. Clavatustide B<smiles>CC1CCCC(CC2Cc3c(O)c(O)cc(O)c3C(=O)O2)O1</smiles>

96. Cladomarine

Figure 8. Bioactive Agents from Fungi Isolated from Multiple Sources (Structures 91 to 96).

In addition to these specific agents, there are two reviews covering marine invertebrates and their symbiotic microbes, one in 2019 by Lui et al. [86] and the other in 2021 by Marchese et al. [87]. Inspection of these recent reviews will give a broader understanding of the value of these marine sources as leads to novel drug candidates. It should also be emphasized at this point that we have only dealt with fungi that can be grown following isolation from marine sources. It is highly probably that there also exist fungi that are as yet unculturable and whose existence is not yet fully confirmed. Such organisms would be similar to the bacterial species described by the Piel group from 2014 onwards $[88,89]$.

\section{Bioactive Compounds from Epigenetic Modifications}

The sequencing of fungal genomes has revealed that we have underestimated their genetic potential to make natural products, as there are many more genes involved in secondary metabolism than detected gene products. For example, the model soil fungus A. nidulans has 28 putative polyketide synthase (PKS) and 24 putative non-ribosomal peptide synthetase (NRPS) gene clusters, demonstrating its capability to produce at least 52 secondary metabolites [90], most of which are silent or cryptic [91].

A variety of techniques have been used to activate these BGCs, including chromatin remodeling, leading to the opening of the cell's chromatin to enable gene transcription. Chromatic remodeling can occur via DNA methylation and histone modification, which affect the transcription of telomere-proximal BGCs and the levels of corresponding metabolites. Histone proteins undergo a wide array of posttranslational modifications that affect 
transcription, including methylation, phosphorylation, acetylation, ubiquitination, and sumoylation. As such, chemical epigenetic modifiers, such as $\mathrm{Zn}^{2+}$-type histone deacetylase (HDAC) and DNA methyltransferase inhibitors, have been added to fermentation media and successfully stimulated the expression of cryptic BGCs [92].

Several studies have reported the induction of cryptic metabolites by supplementing media with chemical epigenetic modifying agents. The HDAC inhibitor suberohydroxamic acid (SBHA) induced the production of a new biphenyl derivative versiperol A (97) in the fermentation of $A$. versicolor MCCC 3A00080, which was isolated from deep-sea sediment (2721 m deep) in the Pacific Ocean [93]. Versiperol A inhibited the growth of S. aureus with an MIC value of $8 \mu \mathrm{g} / \mathrm{mL}$. Other compounds have also been produced by a single strain grown in media containing an HDAC or DNA methyltransferase inhibitor. For example, 5-azacytidine was added to cultures of mangrove-derived $P$. variabile $\mathrm{HXQ}-\mathrm{H}-1$ and reported to produce a new fatty acid amide varitatin A (98) [94]. This fatty acid amide demonstrated cytotoxicity against colon carcinoma (HCT-116) cells with an $\mathrm{IC}_{50}$ value of $2.8 \mu \mathrm{M}$. It also inhibited protein tyrosine kinases, such as PDGFR- $\beta$ and ErbB4 kinases with inhibitory rates of $50 \%$ and $40 \%$, respectively, at a concentration of $1 \mu \mathrm{M}$. When the same strain was cultivated in the presence of the HDAC inhibitor suberoylanilide hydroxamic acid (SAHA), four new compounds, varilactones $\mathrm{A}$ and $\mathrm{B}$, and wortmannilactones $\mathrm{M}$ and $\mathrm{N}$ were produced [95]. None of these compounds exhibited cytotoxic activity or antiviral activity against the influenza A (H1N1) virus. However, this is a great example of how structural diversity can be accessed in a single strain via the addition of epigenetic modifiers.

Many compounds exhibiting non-cytotoxic or non-infective bioactivities have been reported from deep-sea fungi grown in the presence of DNA or HDAC inhibitors. Readers should consult the work of Wang et al. [96], Beau et al. [97], and Zhang et al. [98] for details of the new fungal metabolites induced by the addition of DNA and HDAC inhibitors.

\section{OSMAC}

One strain-many compounds (OSMAC) is another successful approach used to elicit the production of cryptic metabolites. This is actually a renaming of a very old system used initially by antibiotic researchers in the pharmaceutical industry, but never formally published as such. As an example, one of the authors (DJN) was using this technique as a laboratory assistant in the UK in the late 1950s. Since all industrial researchers knew what was used as media components by colleagues in other pharmaceutical and/or agrichemical houses due to frequent personnel movement between companies, there was no need for any formal paper. This also applied up through the 1980s in industry as well.

The first "formal academic publication" discussing these multiple media techniques was published by Zahner in 1979 though it was based on a lecture in 1977 [99]. In addition, in 1982, a book covering the methods for search and discovery of bioactive microbial products was published by the UK "Society for General Microbiology" that included a relevant article by Zahner, based on his earlier publications, but the essential point was that of the three editors, two were from the UK pharmaceutical industry who were involved in the active search for novel antibiotics, whilst the third editor was at the Microbial Chemistry laboratory at the University of Manchester [100]. This book was not well known outside of UK and EU microbial researchers, but the essential point is that it preceded the "nominal OSMAC" story by 20 years. The current term for this old technique "OSMAC" came from a paper in 2002 by Bode et al. [2], but no attribution was given to Zahner's earlier published work which was known in German academic circles.

With all microbes, including fungi, the methods involve a systematic modification of cultivation conditions to trigger cryptic gene clusters, as microbial metabolomics change in response to stress stimuli (e.g., $\mathrm{pH}$, temperature, and the addition of metals, antibiotics, and flavonoids) [101]. In addition to varying cultivation parameters, fermentation media can also be supplemented with precursors and enzyme inhibitors [102]. This approach has successfully induced several compounds in marine fungal cultures, especially in Spicaria elegans KLA03 CCTCC M 205049. For example, Lin and coworkers reported the 
production of new cytochalasins, aspochalasins (M-Q), and spicochalasin A (99) when S. elegans from marine sediment in Jiaozhou Bay, China was cultivated on $2 \%$ starch as the sole carbon source [103]. Spicochalasin A (99) with an unusual pentacyclic system, exhibited cytotoxic activity against human leukemic (HL-60) cells with an $\mathrm{IC}_{50}$ value of $19.9 \mu \mathrm{M}$. A revised structure was published by a different group under the name flavichalasine D in 2021, with structure (99) being the revised version [104]. Interestingly, the same gene cluster that produced spicochalasin A produced nine new cytochalasins, when grown on glucose, demonstrating the effects primary metabolism can have on secondary metabolism $[105,106]$.

Simply varying salinity has induced the production of structurally diverse fungal metabolites. The endophytic Nigrospora sp. MA75 isolated from the marine semi-mangrove plant Pongamia pinnata was found to produce a mixed polyketide-terpenoid, 2,3-didehydro$19 \alpha$-hydroxy-14-epicochlioquinone B (100), when cultivated in media containing 3.5\% $\mathrm{NaCl}$ [107]. Two new griseofulvin derivatives, 6-O-desmethyldechlorogriseofulvin and 6 -hydroxy-griseofulvin, were also isolated when the same strain was cultured on solid rice medium. In addition to antibacterial activity, compound $\mathbf{1 0 0}$ exhibited cytotoxic activities against human breast cancer (MCF-7), pancreatic cancer (SW1990), and hepatocellular cancer (SMMC7721) cell lines with $\mathrm{IC}_{50}$ values of 4, 5, and $7 \mu \mathrm{g} / \mathrm{mL}$, respectively [107].

When Aspergillus sp. SCSIO F063 isolated from a deep-sea sediment in the South China Sea was cultured in potato dextrose broth supplemented with $3 \%$ sea salt, seven new chlorinated anthraquinones were produced. (1'S)-7-Chloroaverantin, (1'S)-6-O-methyl7-chloroaverantin (101), (1'S)-1'-O-methyl-7-chloroaverantin, (1'S)-6,1'-O,O-dimethyl-7chloroaverantin, $\left(1^{\prime} S\right)$-7-chloroaverantin-1'-butyl ether, 7-chloroaverythrin, and 6-O-methyl7-chloroaverythrin are anthraquinones with a chlorine atom at C-7 as well as different methoxy, n-butyl, and unsaturated alkyl chain groups [108]. Two new brominated compounds were produced when the culture broth of the same strain was supplemented with $3 \%$ sodium bromide. Of all of the new metabolites produced, only 6-O-methyl7-chloroaverantin (101) exhibited strong cytotoxic activity against human glioblastoma (SF-268), breast cancer (MCF-7), and lung cancer (NCI-H460) cell lines with $\mathrm{IC}_{50}$ values of $7.11,6.64$, and $7.42 \mu \mathrm{M}$, respectively.

When grown in media containing $10 \%$ saline, S. elegans KLA03 isolated from a marine sediment in Jiaozhou Bay, China produced $\left(2 E, 2^{\prime} Z\right)-3,3^{\prime}-\left(6,6^{\prime}\right.$-dihydroxybiphenyl-3, $3^{\prime}$ diyl)diacrylic acid (102) [109]. Compound 102 exhibited antibacterial activity against Pseudomonas aeruginosa and E. coli with MIC values of $0.038 \mathrm{mM}$ and $0.767 \mathrm{mM}$, respectively. When Luan et al. grew the same strain in a mannitol-based medium using ammonium chloride as the nitrogen source, it produced a small amount of a rare, unstable, highly oxygenated spiro[isobenzofuran-1,3'-isochroman] ring system, eleganketal A (103), which could not be evaluated for bioactivity, but the structure was confirmed by synthesis of the permethylated derivative [110].

Thus, simply modifying salinity and/or the halide ion can produce a variety of bioactive agents hopefully providing enough material that can be isolated for biological evaluation, or alternatively the agent might be synthesized. As examples of varying the halide, a new radical scavenging brominated isocoumarin, $(R)-(-)$-5-bromomellein (104) was also produced once sodium bromide was added to the fermentation broth of the fungus $A$. ochraceus isolated from the marine red alga Chondria crassicualis collected in Korea [111]. Compound (104) exhibited radical scavenging activity against 1,1-diphenyl-2-picrylhydrazyl radical 2,2-diphenyl-1-(2,4,6-trinitrophenyl) hydrazyl (DPPH) with an $\mathrm{IC}_{50}$ value of $24 \mu \mathrm{M}$, which was comparable to the L-ascorbic acid positive control $\left(\mathrm{IC}_{50}=20 \mu \mathrm{M}\right)$.

Supplementing the fermentation broth with amino acids can produce amino acid derivatives, again a technique known from many years earlier as "precursor-directed biosynthesis". Wang and coworkers used this strategy to obtain new cytochalasins from an S. elegans KLA03 strain. Three new cytochalasins, cytochalasins $Z_{21}$ (105), $Z_{22}$ (106), and $\mathrm{Z}_{23}$ were produced when cultures were supplemented with L- and D-tryptophan [112]. Cytochalasins are derived from acetate, a methionine-derived octa- or nonaketide chain, and 
an amino acid. Notably, cytochalasins $Z_{21}(\mathbf{1 0 5})$ and $Z_{22}(\mathbf{1 0 6})$ exhibited cytotoxic activity against human lung adenocarcinoma (A-549) with $\mathrm{IC}_{50}$ values of 8.2 and $20.0 \mu \mathrm{M}$, respectively.

The addition of L-tryptophan and L-phenylalanine to the fermentation broth of Dichotomomyces cejpii F31-1 isolated from the soft coral Lobophytum crassum collected in the South China Sea has also led to the production of several new compounds [113]. Four amides, dichotomocejs A (107) to D, one polyketide dichocetide A, and two diketopiperazines dichocerazines A-B were produced. Dichotomocej A (107) exhibited weak activity against the human rhabdomyosarcoma cell line RD with an $\mathrm{IC}_{50}$ value of $39.1 \mu \mathrm{M}$. The other dichotomocejs were not evaluated but it would be interesting to see how the differing structural substitutions might have altered their biological activity.

Metals have been added to fermentation broths to induce the production of new metabolites. Free metals can function as a "chemical switch" and upregulate biosynthetic pathways or they can be used in either dissimilatory or assimilatory reactions. Some organisms, such as hydrothermal vent microorganisms, are particularly sensitive to changes in the concentrations of available metals, such as copper, and produce new metabolites, many of which have not been assessed for bioactivity [114-116]. Wang et al. [117], reported that Ascotricha sp. ZJ-M-5 isolated from coastal mud in Fenghua County, Zhejiang Province, China produced new caryophyllene derivatives, (+)-6-O-demethylpestalotiopsin A (108), (+)-6-O-demethyl-pestalotiopsin C (109), and (-)-6-O-demethylpestalotiopsin B, when cultivated in Czapek Dox broth with or without $\mathrm{Mg}^{2+}$. This is the first time caryophyllene derivatives have been detected in Ascotricha cultures. (+)-6-O-Demethylpestalotiopsin A (108) and (+)-6-O-demethyl-pestalotiopsin C (109, Figure 9) exhibited growth inhibitory activity against human promyelocytic leukemia $\left(\mathrm{HL}-60 ; \mathrm{GI}_{50}=6.9\right.$ and $\left.8.5 \mu \mathrm{M}\right)$ and human chronic myelogenous leukemia $\left(\mathrm{K}_{562} ; \mathrm{GI}_{50}=10.1\right.$ and $\left.12.3 \mu \mathrm{M}\right)$ cell lines.

Switching from liquid to solid media can also trigger the production of new metabolites. For example, nine new $\mathrm{C}_{9}$ polyketides were produced by the hydrothermal ventderived Aspergillus sp. 16-02-1 (Lau Basin hydrothermal vent, southwest Pacific at $2255 \mathrm{~m}$ and $114^{\circ} \mathrm{C}$ ) when grown on rice [118], as opposed to a liquid medium, which only produced known compounds [119]. When re-fermented on solid substrate, aspiketolactonol (110), aspilactonols A-F (though $\mathrm{E}$ and $\mathrm{F}$ are an unseparated mixture of epimers) (111-115), aspyronol (116), epiaspinonediol (117), and five new ambuic acid derivatives were produced. Compounds 110-115 are $\alpha, \beta$-unsaturated $\gamma$-lactones with varying degrees of oxygenation, whereas compound $\mathbf{1 1 6}$ is an $\alpha, \beta$-unsaturated $\delta$-lactone ring and compound 117 is a branched, acyclic $C_{8}$ carbon chain with a conjugated diene moiety. All compounds (110-117) inhibited human leukemia and gastric cancer cell lines (K562, HL-60, and BGC823 cells) to varying degrees. Aspyronol (116) and epiaspinonediol (117) were more potent and selective cytotoxic agents on human leukemia (K562 and HL-60) cell lines.

When Guo and coworkers switched from growing a deep-sea-derived Penicillium sp. F23-2 (from a Chinese deep ocean sediment at $5080 \mathrm{~m}$ ) in complex liquid media to a rice-based solid medium [120], penicyclones A-E (118-122) were produced. This strain was already reported to produce meleagrins, roquefortines, and terpenoids in a potatobased medium under static conditions and sorbicillinoids in peptone yeast glucose broth medium with agitation. Penicyclones A-E (118-122) differ in their degrees of oxygenation, unsaturation, and alkyl chain length. Yet, all compounds exhibited antimicrobial activity against $S$. aureus with MIC values ranging from 0.3 to $1.0 \mu \mathrm{g} / \mathrm{mL}$.

Simple changes in fermentation vessels can also improve yields and reduce processing times. For example, the yields of the antibiotics ascosetin (123) and lindgomycin (124, Figure 10) from an Arctic-sourced Lindgomycetaceae isolated from the sponge Halichondria panicea, improved by a factor of 100 once transferred from an Erlenmeyer flask to a stirred tank reactor [121]. 
<smiles>COc1ccc(O)cc1-c1cc(O)ccc1OC</smiles>

97. Versiperol A

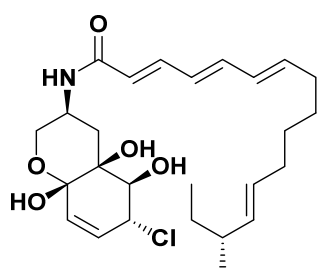

98. Varitatin A

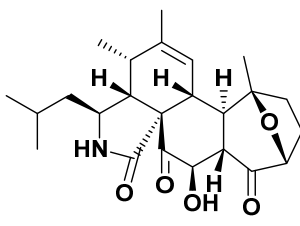

99. Spicochalasin A<smiles>CC[C@H](C)C(=O)[C@H](C)C1=CC(=O)C2=C(O[C@]3(C)CC[C@H]4C[C@H](C(C)(C)O)C[C@@H](O)[C@]4(C)[C@]3(C)C2)C1=O</smiles>

100. 2,3-didehydro-19 $\alpha$-hydroxy14-epicochlioquinone $B$<smiles>CC1Cc2c(Br)ccc(O)c2C(=O)O1</smiles>

104. (R)-(-)-5-Bromomellein<smiles>C/C=C/C=C(\C)C(=O)NC(CO)CC(C)C</smiles>

107. Dichotomocej A<smiles>O=C(O)/C=C\c1ccc(O)c(-c2cc(/C=C/C(=O)O)ccc2O)c1</smiles>

102. (2E,2'Z)-3,3'-(6,6'-dihydroxy biphenyl-3,3'-diyl)diacrylic acid<smiles>Cc1c(O)c(O)c(O)c2c1COC1(OCc3c(C)c(O)c(O)c(O)c31)O2</smiles>

103. Eleganketal A<smiles></smiles>

105. Cytochalasin $Z_{21}$

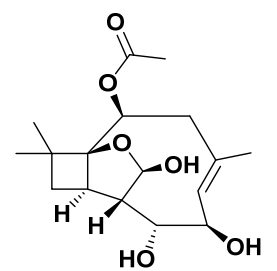

108. (+)-6-O-Demethylpestalotiopsin A

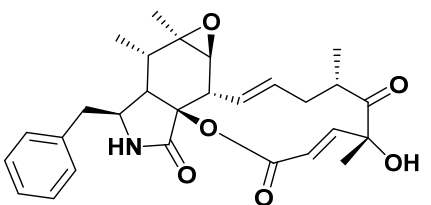

106. Cytochalasin $Z_{22}$

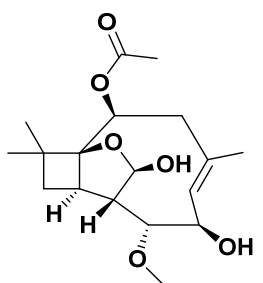

109. (+)-6-O-Demethylpestalotiopsin C

Figure 9. Modification of Media Components/Fermentation Conditions I (Structures 97-109).

Environmental cues, such as temperature, can trigger the expression of silent gene clusters. Liu and coworkers reported five new polyketides produced from P. raistrickii JH-18 isolated from coastal marine soil from Bohai Bay, China once the fermentation temperature was lowered from $28^{\circ} \mathrm{C}$ to $15^{\circ} \mathrm{C}$ [122]. The change in the temperature significantly altered the $P$. raistrickii JH-18 metabolome and new raistrickione diastereomers, raistrickiones A-C (125-127), and analogs, raistrickiones D and E (128-129), were produced. Raistrickiones A-E exhibited radical scavenging activity against $\mathrm{DPPH}$ with $\mathrm{IC}_{50}$ values of 32, 38, 40, 49, and $42 \mu \mathrm{M}$, respectively. The $\mathrm{IC}_{50}$ value of the ascorbic acid positive control was $17 \mu \mathrm{M}$. It would be interesting to know the optimal growth temperature of this Penicillium strain to understand why these metabolites are produced.

Supplementing culture media with enzyme inhibitors has also led to the production of new bioactive compounds. For example, based on several species of Phomopsis and Chaetomium sp. producing well-known actin depolymerizers (i.e., chaetoglobosins), the Crews group added an actin inhibitor to induce the production of unprecedented chaetoglobosins. Three new chaetoglobosins with various levels of oxygenation, chaetoglobosin-510, -540 , and -542 (130), were produced when the actin inhibitor jasplakinolide (aka jaspamide) was added to cultures of Phomopsis asparagi isolated from the sponge Rhaphidophlus juniperina 
collected from the US Virgin Islands [123]. Chaetoglobosin-542 (131) exhibited antimicrofilament activity at $1 \mu \mathrm{g} / \mathrm{mL}$ as well as cytotoxic activity against murine colon and leukemia cell lines but was also toxic toward murine normal bone marrow (CFU-GM).<smiles>CC(=O)CC1=CC(C(C)O)OC1=O</smiles>

110. Aspiketolactonol<smiles>CC(O)CCC1=CC(C)OC1=O</smiles>

111. Aspilactonol A<smiles></smiles>

112. Aspilactonol $B$<smiles>CC(O)[C@H](O)C1=CC([C@@H](C)O)OC1=O</smiles>

113. Aspilactonol C<smiles>CO[C@@H](C1=CC(C(C)O)OC1=O)[C@H](C)O</smiles><smiles>CC(O)CC1=CC([C@H](C)O)OC1=O</smiles><smiles>CO[C@@H](C1=C[C@H](O)[C@@H](C)OC1=O)C(C)O</smiles><smiles>CC(=O)/C=C/C(=C/[C@@H](C)O)CO</smiles>

114. Aspilactonol $D$ 115. Aspilactonol E/F

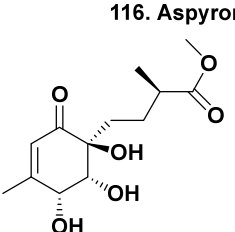
ö̀ 120. Penicyclone C<smiles>CC1=CC(=O)[C@](O)(CC[C@H](C)C(=O)O)[C@H](O)C1</smiles>

ồH

119. Penicyclone B<smiles>CC1=CC(=O)[C@@]2(CC/C(C)=C/CC(=O)O)O[C@H]2[C@H](O)C(C)=C1</smiles>

21. Penicyclone D

118. Penicyclone A

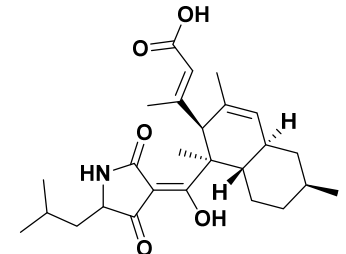

123. Ascosetin

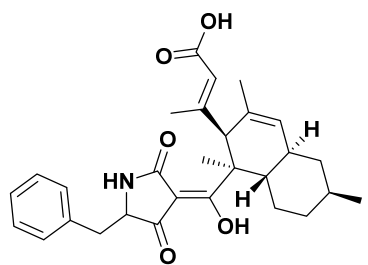

124. Lindgomycin

Figure 10. Modification of Media Components / Fermentation Conditions II (Structures 110-124).

Other enzyme inhibitors, such as the P-450 dependent monooxygenase inhibitor metyrapone, have been used to induce the production of new metabolites [124]. For more information on the application of these well-known principles to marine fungi, see the reviews by Reen et al. [125] and Romano et al. [126].

\section{Optimization of Growth Conditions and Strains for Large-Scale Production}

A common problem in finding new bioactive fungal metabolites is not having enough isolated material for biological evaluation. However, metabolite production can be further optimized by modifying growth conditions. For example, altering the salinity has also improved the yields of the antibiotics obioninene (131) as well as corollosporine (132) and derivatives (in the presence of laccase treatment) produced by driftwood-derived Leptosphaeria oraemaris [127], and Corollospora maritime [128,129]. Time is also an important factor that has been found to influence the accumulation or depletion of metabolites, with several studies reporting the impact of time on activating hidden metabolomes [130].

Several variables can be modified at once to optimize the yields of isolated fungal metabolites. For example, in optimized medium, cultivation time of three days, and $28^{\circ} \mathrm{C}$ growth temperature, the yield of the antibacterial, lipodepsipeptide 15G256 $\gamma$ (133) produced by mangrove-derived Hypoxylon oceanicum LL-15G256 (Shenzen, China) increased from $\sim 50$ to $400 \mathrm{mg} / \mathrm{L}$ [131]. In addition, simple modifications in $\mathrm{pH}$ and growth time were also shown to be important for producing optimal amounts of the antibacterial exophilin A (134), which was produced by Exophilia pisciphila isolated from the sponge Mycale adhaerans [132]. Furthermore, spore inoculation, low agitation (50 rpm) and pH (4.5), an aeration rate of $0.33 \mathrm{vvm}$, and a 2 -fold amount of maltose and glucose on the sixth day of growth in cultures of A. terreus PF-26 (isolated from the sponge Phakellia fusca) 
grown in a stirred 5-L reactor led to a 1.65-fold increase in (+)-terrein, (135) a cytotoxic antibiotic to $2.68 \mathrm{~g} / \mathrm{L}$ ) [133]. While these modifications have been successful, using the "one-factor-at-a-time" approach can be time-consuming and does not reveal the interactions of various parameters.

Controlled and targeted methods, involving statistical analyses, can modify multiple variables simultaneously. Alternative methodologies, including orthogonal array designs, Plackett-Burman, and response surface methodologies (RSM), have been developed to optimize product yields by examining the effects of multiple variables in parallel in a minimal set of experiments.

Genichi Taguchi developed the orthogonal array design, a statistical method that determines how different parameters affect product yields in the smallest number of experiments, without having to explore all possible combinations [134]. Though somewhat "dated" this strategy provides the significant and optimal contributions of each variable.

The Plackett-Burman experimental design, though originally published in 1946, measures the dependence of a measured quantity on various complex media components in a way that minimizes the variance of these dependencies using a limited number of experiments [135]. This technique was utilized extensively in the earlier days of antibiotic production when companies wished to reduce the sizes of their production fermentors.

RSM is another sequential technique that involves designing experiments, mathematical models, and statistical analyses to explore relationships between a response variable and a set of design variables [136]. This approach determines influential factors and how they interact with each other, revealing the role of each component in the optimization process.

Orthogonal array designs, Plackett-Burman designs, and RSM were all used to increase the yield of the antineoplastic compound aspergiolide A (136) from the marinederived A. glaucus HB1-19 by 4.22-fold $(71.2 \mathrm{mg} / \mathrm{L})[137,138]$. RSM was also used to optimize the antineoplastic, antibiotic penicilazaphilone $C(137)$ produced by the marinederived fungus P. sclerotiorum M-22, first reported by Zhou et al. in 2016 [139], and then optimized increasing the yield by 1.344-fold [140].

DNA modifications and genetic engineering have also been used to coerce fungal strains into producing higher yields. For example, ultraviolet radiation was used to mutate the DNA of Scopulariopsis brevicaulis LF580 to optimize the yield of the sponge-derived scopularide A (138) [141]. This cyclic peptide whose structure was revised in 2016 [142], exhibited cytotoxic activity against pancreatic and colon tumor cells $[143,144]$. In this optimization work, a faster-growing UV-mutated strain (LF580-M26) that rapidly produced more scopularide A was identified. The LF580-M26 strain showed differences in pellet formation, which is relevant as proteomics revealed the wild-type strain's limited nutrient availability due to its robust pellet formation.

Genetic engineering has also improved metabolite yields by (in)activating genomic segments via the manipulation of regulators or chromatin-modifying enzymes. Scopularide A (138, Figure 11) was optimally produced by S. brevicaulis LF580 once its biosynthetic gene cluster was identified [145]. The following papers and reviews give more information on producing bioactive fungal metabolites via genetic engineering $[91,146,147]$.<smiles>Cc1c(O)cc(C(=O)C(O)C2CCC(C)O2)cc1O</smiles>

125. Raistrickione A

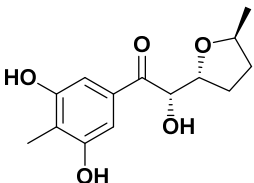

126. Raistrickione $B$

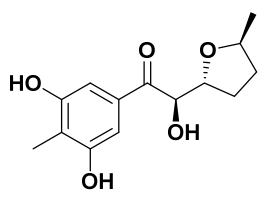

127. Raistrickione C

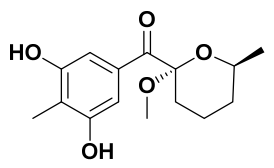

128. Raistrickione D

Figure 11. Cont. 
<smiles>Cc1c(O)cc(C(=O)C2=CCC[C@H](C)O2)cc1O</smiles>

129. Raistrickione $E$<smiles>CCCCCCC1(O)OC(=O)c2c(O)cccc21</smiles>

132 Corollosporine

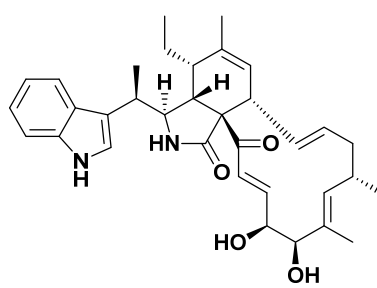

130. Chaetoglobosin-542<smiles>CCC(C)/C=C(\C)C1=CC2=Cc3cc(OC)c(cc3C(=O)C2=O)CO1</smiles>

131. Obioninene

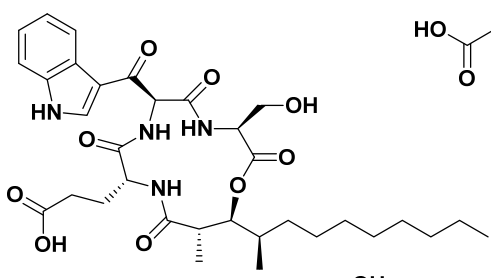<smiles>CCCCC[C@H](O)CC(O)CC(=O)O[C@H](CCCCC)CC(O)CC(=O)O[C@H](CCCCC)CC(O)CC(=O)O</smiles>

134. Exophilin A

133. 15G256<smiles></smiles><smiles>CCC(C)C(O)C(C)(O)C(O)C=CC1=CC2=C(Cl)C(=O)[C@](C)(O)[C@H](O)C2CO1</smiles>

137. Penicilazaphilone $C$

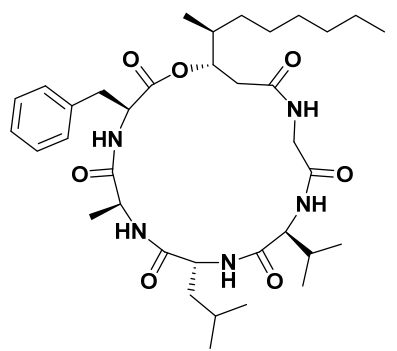

138. Scopularide A

Figure 11. Modification of Media Components / Fermentation Conditions III (Structures 125-138).

\section{Materials Produced by Both Terrestrial and Marine Isolates}

Let us also not forget that several "marine" natural products are also produced by terrestrial endophytic fungi, some of which are more amenable to optimizing product yields. For example, the antifungal zofimarin (139, Figure 12) was originally isolated from the marine fungus Zopfiella marina SANK21274 but was later isolated from the fermentation broth of Xylaria sp. Acra L38 from the Thai medicinal plant Aquilaria crassna [148]. Chaichanan and coworkers grew Xylaria sp. Acra L38 in sucrose, maltose, glucose, and sodium nitrate and increased the zofimarin yield 8-fold compared to when it was grown in Czapek yeast extract. Many of the natural products discussed here, especially those that are mangrove-derived, may also be produced by terrestrial fungi, which could be explored for greater product supplies. 


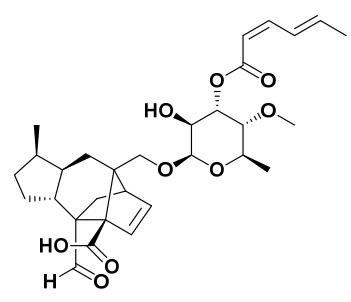

139. Zofimarin

Figure 12. Zofimarin, a Fungal Metabolite from Land and Sea (Structure 139).

\section{Conclusions}

While we will continue to see an upward trend in the number of bioactive metabolites from marine fungi with increased marine exploration, several underrated strategies should be considered moving forward. Marine fungi are typically grown using the same cultivation methods used with terrestrial fungi, which rarely reflect the metabolic demands of marine fungi. Thus, increased collaborations between natural product chemists and mycologists, as described by Reich and Labes in a paper in Marine Genomics in December 2017 [149], would aid in 'unlocking' more fungal metabolomes from the sea. Most fungal strains discussed in this review belong to cosmopolitan genera, such as Penicillium and Aspergillus; however, mycologists have strategies for isolating and cultivating unique marine fungal isolates.

Advances in culturing, screening, and culture-independent techniques will also allow us to access more metabolites from extremophilic fungi, resulting in increased chemical diversity and bioactivity [150]. The cocultivation of marine fungi with other organisms, including with fungi should be considered, as exemplified by the Stierle group at the University of Montana in a paper a year earlier [151]. This fermentation method takes advantage of symbiotic or competitive growth conditions to trigger secondary metabolite production via upregulating silent genes. Regarding screening and culture-independent approaches, readers should consult the recent paper by Nie et al. [152], the reviews by Lage et al. [153] and Wang et al. [154], to see how these research areas are also providing investigators with tools to access bioactive fungal metabolites.

Lastly, more research groups from China are publishing on bioactive metabolites from marine microorganisms with a focus on fungi [35]. This trend might represent a shift with reports being published in international journals instead of Chinese journals, but we expect to see more publications from this region, especially on compounds produced by mangrove endophytic fungi. For more bioactive fungal metabolites from the sea, we recommend reading the special 2020 issues from Marine Drugs, "Bioactive Compounds from Marine Sediment Derived Fungi" and "Natural Products from Marine Fungi" which are freely available on the Marine Drugs website.

Funding: This research received no external funding.

Conflicts of Interest: The authors declare no conflict of interest.

\section{References}

1. Newman, D.J.; Cragg, G.M. Natural products as sources of new drugs over the nearly four decades from 01/1981 to 09/2019. J. Nat. Prod. 2020, 83, 770-803. [CrossRef]

2. Bode, H.B.; Bethe, B.; Höfs, R.; Zeeck, A. Big effects from small changes: Possible ways to explore nature's chemical diversity. ChemBioChem 2002, 3, 619-627. [CrossRef]

3. Harvey, A.L.; Edrada-Ebel, R.; Quinn, R.J. The re-emergence of natural products for drug discovery in the genomics era. Nat. Rev. Drug Discov. 2015, 14, 111-129. [CrossRef] [PubMed]

4. Giddings, L.-A.; Newman, D.J. Bioactive compounds from marine extremophiles. In Extremophilic Bacteria, Springer Briefs in Microbiology; Tiquia-Arashiro, S.M., Mormile, M., Eds.; Springer: Cham, Switzerland, 2015; pp. 1-150. [CrossRef]

5. Schulz, B.; Draeger, S.; de la Cruz, T.E.; Rheinheimer, J.; Siems, K.; Loesgen, S.; Bitzer, J.; Schloerke, O.; Zeeck, A.; Kock, I.; et al. Screening strategies for obtaining novel, biologically active, fungal secondary metabolites from marine habitats. Bot. Mar. 2008, 51, 219-234. [CrossRef] 
6. Keller, N.P.; Turner, G.; Bennett, J.W. Fungal secondary metabolism-from biochemistry to genomics. Nat. Rev. Micro. 2005, 3, 937-947. [CrossRef] [PubMed]

7. Rokas, A.; Mead, M.E.; Steenwyk, J.L.; Raja, H.A.; Oberlies, N.H. Biosynthetic gene clusters and the evolution of fungal chemodiversity. Nat. Prod. Rep. 2020, 37, 868-878. [CrossRef] [PubMed]

8. Overy, D.P.; Rama, T.; Oosterhuis, R.; Walker, A.K.; Panf, K.-L. The neglected marine fungi, sensu stricto, and their isolation for natural products' discovery. Mar. Drugs 2019, 17, 42. [CrossRef] [PubMed]

9. Giddings, L.-A.; Newman, D.J. Bioactive compounds from extremophilic marine fungi. In Fungi in Extreme Environments: Ecological Role and Biotechnological Significance; Tiquia-Arashiro, S.M., Grube, M., Eds.; Springer: Cham, Switzerland, 2019 ; pp. 349-382. [CrossRef]

10. Liu, Z.; Chen, Y.; Li, S.; Wang, Q.; Hu, C.; Liu, H.; Zhang, W. Bioactive metabolites from the deep-sea-derived fungus Diaporthe longicolla fs429. Mar. Drugs 2020, 18, 381. [CrossRef]

11. Zhang, Z.; He, X.; Liu, C.; Che, Q.; Zhu, T.; Gu, Q.; Li, D. Clindanones A and B and cladosporols F and G, polyketides from the deep-sea derived fungus Cladosporium cladosporioides HDN14-342. RSC Adv. 2016, 6, 76498-76504. [CrossRef]

12. Li, H.-L.; Li, X.-M.; Mándi, A.; Antus, S.; Li, X.; Zhang, P.; Liu, Y.; Kurtán, T.; Wang, B.-G. Characterization of cladosporols from the marine algal-derived endophytic fungus Cladosporium cladosporioides EN-399 and configurational revision of the previously reported cladosporol derivatives. J. Org. Chem. 2017, 82, 9946-9954. [CrossRef]

13. Xu, J.-L.; Liu, H.-X.; Chen, Y.-C.; Tan, H.-B.; Guo, H.; Xu, L.-Q.; Li, S.-N.; Huang, Z.-L.; Li, H.-H.; Gao, X.-X.; et al. Highly substituted benzophenone aldehydes and eremophilane derivatives from the deep-sea derived fungus Phomopsis lithocarpus FS508. Mar. Drugs 2018, 16, 329. [CrossRef] [PubMed]

14. Zhang, Z.; Guo, W.; He, X.; Che, Q.; Zhu, T.; Gu, Q.; Li, D. Peniphenylanes A-G from the deep-sea-derived fungus Penicillium fellutanum HDN14-323. Planta Med. 2016, 82, 872-876. [CrossRef]

15. Gao, X.-W.; Liu, H.-X.; Sun, Z.-H.; Chen, Y.-C.; Tan, Y.-Z.; Zhang, W.-M. Secondary metabolites from the deep-sea derived fungus Acaromyces ingoldii FS121. Molecules 2016, 21, 371. [CrossRef]

16. Wang, W.; Li, S.; Chen, Z.; Li, Z.; Liao, Y.; Chen, J. Secondary metabolites produced by the deep-sea-derived fungus Engyodontium album. Chem. Nat. Compds. 2017, 53, 224-226. [CrossRef]

17. Li, Y.; Ye, D.; Chen, X.; Lu, X.; Shao, Z.; Zhang, H.; Che, Y. Breviane spiroditerpenoids from an extreme-tolerant Penicillium sp. isolated from a deep sea sediment sample. J. Nat. Prod. 2009, 72, 912-926. [CrossRef] [PubMed]

18. Li, Y.; Ye, D.; Shao, Z.; Cui, C.; Che, Y. A sterol and spiroditerpenoids from a Penicillium sp. isolated from a deep sea sediment sample. Mar. Drugs 2012, 10, 497-508. [CrossRef]

19. Li, D.; Wang, F.; Cai, S.; Zeng, X.; Xiao, X.; Gu, Q.; Zhu, W. Two new bisorbicillinoids isolated from a deep-sea fungus, Phialocephala sp. Fl30r. J. Antibiot. 2007, 60, 317-320. [CrossRef] [PubMed]

20. Li, D.; Cai, S.; Zhu, T.; Wang, F.; Xiao, X.; Gu, Q. Three new sorbicillin trimers, trisorbicillinones B, C and D, from a deep ocean sediment derived fungus, Phialocephala sp. Fl30r. Tetrahedron 2010, 66, 5101-5106. [CrossRef]

21. Li, D.-H.; Cai, S.-X.; Zhu, T.-J.; Wang, F.-P.; Xiao, X.; Gu, Q.-Q. New cytotoxic metabolites from a deep-sea-derived fungus, Phialocephala sp., strain FL30r. Chem. Biodiv. 2011, 8, 895-901. [CrossRef] [PubMed]

22. Niu, S.; Liu, D.; Shao, Z.; Proksch, P.; Lin, W. Eutypellazines A-M, thiodiketopiperazine -type alkaloids from deep sea derived fungus Eutypella sp. MCCC 3A00281. RSC Adv. 2017, 7, 33580-33590. [CrossRef]

23. Niu, S.; Liu, D.; Shao, Z.; Proksch, P.; Lin, W. Eutypellazines N-S, new thiodiketo-piperazines from a deep sea sediment derived fungus Eutypella sp. With anti-VRE activities. Tetrahedron Lett. 2017, 58, 3695-3699. [CrossRef]

24. Bao, J.; Zhai, H.; Zhu, K.; Yu, J.-H.; Zhang, Y.; Wang, Y.; Jiang, C.-S.; Zhang, X.; Zhang, Y.; Zhang, H. Bioactive pyridone alkaloids from a deep-sea-derived fungus Arthrinium sp. UJNMF0008. Mar. Drugs 2018, 16, 174. [CrossRef]

25. Xu, X.; Zhang, X.; Nong, X.; Wang, J.; Qi, S. Brevianamides and mycophenolic acid derivatives from the deep-sea-derived fungus Penicillium brevicompactum DFFSCS025. Mar. Drugs 2017, 15, 43. [CrossRef] [PubMed]

26. Fredimoses, M.; Zhou, X.; Lin, X.; Tian, X.; Ai, W.; Wang, J.; Liao, S.; Liu, J.; Yang, B.; Yang, X.; et al. New prenylxanthones from the deep-sea derived fungus Emericella sp. SCSIO 05240. Mar. Drugs 2014, 12, 3190-3202. [CrossRef] [PubMed]

27. Wang, J.; He, W.; Huang, X.; Tian, X.; Liao, S.; Yang, B.; Wang, F.; Zhou, X.; Liu, Y. Antifungal new oxepine-containing alkaloids and xanthones from the deep-sea-derived fungus Aspergillus versicolor SCSIO 05879. J. Agric. Food Chem. 2016, 64, 2910-2916. [CrossRef]

28. Wang, W.; Chen, R.; Luo, Z.; Wang, W.; Chen, J. Antimicrobial activity and molecular docking studies of a novel anthraquinone from a marine-derived fungus Aspergillus versicolor. Nat. Prod. Res. 2017, 32, 558-563. [CrossRef]

29. Du, L.; Yang, X.; Zhu, T.; Wang, F.; Xiao, X.; Park, H.; Gu, Q. Diketopiperazine alkaloids from a deep ocean sdiment derived fungus Penicillium sp. Chem. Pharm. Bull. 2009, 57, 873-876. [CrossRef] [PubMed]

30. Niu, S.; Fan, Z.-W.; Xie, C.-L.; Liu, Q.; Luo, Z.-H.; Liu, G.; Yang, X.-W. Spirograterpene a, a tetracyclic spiro-diterpene with a fused 5/5/5/5 ring system from the deep-sea-derived fungus Penicillium granulatum MCCC 3A00475. J. Nat. Prod. 2017, 80, 2174-2177. [CrossRef]

31. Bandaranayake, W.M. Traditional and medicinal uses of mangroves. Wetl. Ecol. Manag. Mangroves Salt Marshes 1998, 2, 133-148. [CrossRef]

32. Thatoi, H.; Behera, B.C.; Mishra, R.R. Ecological role and biotechnological potential of mangrove fungi: A review. Mycology 2013, 4, 54-71. [CrossRef] 
33. Deshmukh, S.K.; Agrawal, S.; Prakash, V.; Gupta, M.K.; Reddy, M.S. Anti-infectives from mangrove endophytic fungi. S. A. J. Bot. 2020, 134, 237-263. [CrossRef]

34. Cadamuro, R.D.; da Silveira Bastos, I.M.A.; Silva, I.T.; Cabral da Cruz, A.C.; Robl, D.; Sandjo, L.P.; Alves, S., Jr.; Lorenzo, J.M.; Rodríguez-Lázaro, D.; Treichel, H.; et al. Bioactive compounds from mangrove endophytic fungus and their uses for microorganism control. J. Fungi 2021, 7, 455. [CrossRef] [PubMed]

35. Sun, W.; Wu, W.; Liu, X.; Zaleta-Pinet, D.A.; Clark, B.R. Bioactive compounds isolated from marine-derived microbes in China: 2009-2018. Mar. Drugs 2019, 17, 339. [CrossRef]

36. Liu, Y.; Xia, G.; Li, H.; Ma, L.; Ding, B.; Lu, Y.; He, L.; Xia, X.; She, Z. Vermistatin derivatives with $\alpha$-glucosidase inhibitory activity from the mangrove endophytic fungus Penicillium sp. HN29-3B1. Planta Med. 2014, 80, 912-917. [CrossRef] [PubMed]

37. Liu, Y.; Yang, Q.; Xia, G.; Huang, H.; Li, H.; Ma, L.; Lu, Y.; He, L.; Xia, X.; She, Z. Polyketides with $\alpha$-glucosidase inhibitory activity from a mangrove endophytic fungus, Penicillium sp. HN29-3B1. J. Nat. Prod. 2015, 78, 1816-1822. [CrossRef]

38. Li, H.; Huang, H.; Shao, C.; Huang, H.; Jiang, J.; Zhu, X.; Liu, Y.; Liu, L.; Lu, Y.; Li, M.; et al. Cytotoxic norsesquiterpene peroxides from the endophytic fungus Talaromyces flavus isolated from the mangrove plant Sonneratia apetala. J. Nat. Prod. 2011, 74, 1230-1235. [CrossRef]

39. Liu, H.; Chen, S.; Liu, W.; Liu, Y.; Huang, X.; She, Z. Polyketides with immunosuppressive activities from mangrove endophytic fungus Penicillium sp. ZJ-SY2. Mar. Drugs 2016, 14, 217. [CrossRef]

40. Cai, R.; Chen, S.; Long, Y.; Li, C.; Huang, X.; She, Z. Depsidones from Talaromyces stipitatus SK-4, an endophytic fungus of the mangrove plant Acanthus ilicifolius. Phytochem. Lett. 2017, 20, 196-199. [CrossRef]

41. Nicoletti, R.; Salvatore, M.M.; Andolfi, A. Secondary metabolites of mangrove-associated strains of Talaromyces. Mar. Drugs 2018, 16, 12. [CrossRef]

42. Lin, Z.J.; Zhu, T.J.; Fang, Y.C.; Gu, Q.Q.; Zhu, W.M. Polyketides from Penicillium sp JP-1, an endophytic fungus associated with the mangrove plant Aegiceras corniculatum. Phytochemistry 2008, 69, 1273-1278. [CrossRef]

43. Xu, M.; Deng, Z.; Li, M.; Li, J.; Fu, H.; Proksch, P.; Lin, W. Chemical constituents from the mangrove plant, Aegiceras corniculatum J. Nat. Prod. 2004, 67, 762-766. [CrossRef]

44. Bandaranayake, W.M. Bioactivities, bioactive compounds and chemical constituents of mangrove plants. Wetlands Ecol. Managmt. 2002, 10, 421-452. [CrossRef]

45. Wang, Y.; Xu, L.; Ren, W.; Zhao, D.; Zhu, Y.; Wu, X. Bioactive metabolites from Chaetomium globosum 118, an endophytic fungus in the medicinal plant Curcuma wenyujin. Phytomedicine 2012, 19, 364-368. [CrossRef]

46. Huang, S.; Chen, H.; Li, W.; Zhu, X.; Ding, W.; Li, C. Bioactive chaetoglobosins from the mangrove endophytic fungus Penicillium chrysogenum. Mar. Drugs 2016, 14, 172. [CrossRef] [PubMed]

47. Li, C.; Gong, B.; Cox, D.G.; Li, C.; Wang, J.; Ding, W. Dichlorodiaportinol a-A new chlorine-containing isocoumarin from an endophytic fungus Trichoderma sp. 09 from Myoporum bontioides a. Gray and its cytotoxic activity. Pharmacogn. Mag. 2014, 10, 153-158. [CrossRef] [PubMed]

48. Li, W.; Xu, J.; Li, F.; Xu, L.; Li, C. A new antifungal isocoumarin from the endophytic fungus Trichoderma sp. 09 of Myoporum bontioides a. Gray. Pharmacogn. Mag. 2016, 12, 259-261. [CrossRef] [PubMed]

49. Li, W.; Xiong, P.; Zheng, W.; Zhu, X.; She, Z.; Ding, W.; Li, C. Identification and antifungal activity of compounds from the mangrove endophytic fungus Aspergillus clavatus R7. Mar. Drugs 2017, 15, 259. [CrossRef] [PubMed]

50. Xie, G.; Zhu, X.; Li, Q.; Gu, M.; He, Z.; Wu, J.; Li, J.; Lin, Y.; Li, M.; She, Z.; et al. SZ-685C, a marine anthraquinone, is a potent inducer of apoptosis with anticancer activity by suppression of the Akt/FOXO pathway. Br. J. Pharmacol. 2010, 159, 689-697. [CrossRef]

51. He, Z.; Li, M.; Jun, L.; Li, M.; Li, W.; Lin, Y.; Liu, H.; She, Z.; Wu, J.; Xia, J.; et al. Application of Anthracycline Compound in Preparing Anti-Breast Cancer Medicines. Patent Number CN101862313, 17 May 2010.

52. Zhu, X.; He, Z.; Wu, J.; Yuan, J.; Wen, W.; Hu, Y.; Jiang, Y.; Lin, C.; Zhang, Q.; Lin, M.; et al. A marine anthraquinone SZ-685C overrides adriamycin-resistance in breast cancer cells through suppressing Akt signaling. Mar. Drugs 2012, 10, 694-711. [CrossRef]

53. Chen, C.-H.; Xiao, W.-W.; Jiang, X.-B.; Wang, J.-W.; Mao, Z.-G.; Lei, N.; Fan, X.; Song, B.-B.; Liao, C.-X.; Wang, H.-J.; et al. A novel marine drug, SZ-685C, induces apoptosis of MMQ pituitary tumor cells by downregulating miR-200c. Curr. Med. Chem. 2013, 20, 2145-2154. [CrossRef]

54. Wang, D.; Wang, S.; Liu, Q.; Wang, M.; Wang, C.; Yang, H. SZ-685C exhibits potent anticancer activity in both radiosensitive and radioresistant npc cells through the miR-205-PTEN-Akt pathway. Oncol. Rep. 2013, 29, 2341-2347. [CrossRef]

55. Wang, X.; Tan, T.; Mao, Z.-G.; Lei, N.; Wang, Z.-Y.; Hu, B.; Chen, Z.-Y.; She, Z.-G.; Zhu, Y.-H.; Wang, H.-J. The marine metabolite SZ-685C induces apoptosis in primary human nnfunctioning pituitary adenoma cells by inhibition of the Akt pathway in vitro. Mar. Drugs 2015, 13, 1569-1580. [CrossRef] [PubMed]

56. Fenical, W.; Jensen, P.R.; Kauffman, C.; Mayhead, S.L.; Faulkner, D.J.; Sincich, C.; Rao, M.R.; Kantorowski, E.J.; West, L.M.; Strangman, W.K.; et al. New anticancer drugs from cultured and collected marine organisms. Pharm. Biol. 2003, 41, 6-14. [CrossRef]

57. Gullo, V.P.; McAlpine, J.; Lam, K.S.; Baker, D.; Petersen, F. Drug discovery from natural products. J. Ind. Microbiol. Biotechnol. 2006, 33, 523-531. [CrossRef]

58. BeyondSpringPharma. Pliabulin and Docetaxel. Available online: https://bit.ly/3inGCfV (accessed on 1 December 2021). 
59. Kim, D.-H.; Brunt, J.; Austin, B. Microbial diversity of intestinal contents and mucus in rainbow trout (Oncorhynchus mykiss). J. Appl. Microbiol. 2006, 102, 1654-1664. [CrossRef]

60. Ward, N.L.; Steven, B.; Penn, K.; Methe, B.A.; Detrich III, W.H. Characterization of the intestinal microbiota of two antarctic notothenioid fish species. Extremophiles 2009, 13, 679-685. [CrossRef] [PubMed]

61. Smriga, S.; Sandin, S.A.; Azam, F. Abundance, diversity, and activity of microbial assemblages associated with coral reef fish guts and feces. FEMS Microbiol. Ecol. 2010, 73, 31-42. [CrossRef] [PubMed]

62. Roeselers, G.; Mittge, E.K.; Stephens, W.Z.; Parichy, D.M.; Cavanaugh, C.M.; Guillemin, K.; Rawls, J.F. Evidence for a core gut microbiota in the zebrafish. ISME J. 2011, 5, 1595-1608. [CrossRef]

63. Sanchez, L.M.; Wong, W.R.; Riener, R.M.; Schulze, C.J.; Linington, R.G. Examining the fish microbiome: Vertebrate-derived bacteria as an environmental niche for the discovery of unique marine natural products. PLoS ONE 2012, 7, e35398. [CrossRef] [PubMed]

64. Numata, A.; Takahashi, C.; Matsushita, T.; Miyamoto, T.; Kawai, K.; Usami, Y.; Matsumura, E.; Inoue, M.; Ohishi, H.; Shingu, T. Fumiquinazolines, novel metabolites of a fungus isolated from a saltfish. Tetrahedron Lett. 1992, 33, 1621-1624. [CrossRef]

65. Takahashi, C.; Matsushita, T.; Doi, M.; Minoura, K.; Shingu, T.; Kumeda, Y.; Numata, A. Fumiquinazolines A-G, novel metabolites of a fungus separated from a Pseudolabrus marine fish. J. Chem. Soc. Perkin Trans. 1995, 1, 2345-2353. [CrossRef]

66. Belofsky, G.N.; Anguera, M.; Jensen, P.R.; Fenical, W.; Kock, M. Oxepinamides A-C and fumiquinazolines H-I: Bioactive metabolites from a marine isolate of a fungus of the genus Acremonium. Chem.-Eur. J. 2000, 6, 1355-1360. [CrossRef]

67. Shao, C.L.; Xu, R.F.; Wei, M.Y.; She, Z.G.; Wang, C.Y. Structure and absolute configuration of fumiquinazoline 1, an alkaloid from a gorgonian-derived Scopulariopsis sp. fungus. J. Nat. Prod. 2013, 76, 779-782. [CrossRef] [PubMed]

68. Resende, D.I.S.P.; Boonpothong, P.; Sousa, E.; Kijjoa, A.; Pinto, M.M.M. Chemistry of the fumiquinazolines and structurally related alkaloids. Nat. Prod. Rep. 2019, 36, 7-34. [CrossRef]

69. Han, J.; Liu, M.; Jenkins, I.D.; Liu, X.; Zhang, L.; Quinn, R.J.; Feng, Y. Genome-inspired chemical exploration of marine fungus Aspergillus fumigatus MF071. Mar. Drugs 2020, 18, 352. [CrossRef] [PubMed]

70. Yamada, T.; Doi, M.; Shigeta, H.; Muroga, Y.; Hosoe, S.; Numata, A.; Tanaka, R. Absolute stereostructures of cytotoxic metabolites, chaetomugilins A-C, produced by a Chaetomium species separated from a marine fish. Tetrahedron Lett. 2008, 49, $4192-4195$. [CrossRef]

71. Yasuhide, M.; Yamada, T.; Numata, A.; Tanaka, R. Chaetomugilins, new selectively cytotoxic metabolites, produced by a marine fish-derived Chaetomium species. J. Antibiot. 2008, 61, 615-622. [CrossRef] [PubMed]

72. Yamada, T.; Yasuhide, M.; Shigeta, H.; Numata, A.; Tanaka, R. Absolute stereostructures of chaetomugilins G and H produced by a marine-fish-derived Chaetomium species. J. Antibiot. 2009, 62, 353-357. [CrossRef] [PubMed]

73. Muroga, Y.; Yamada, T.; Numata, A.; Tanaka, R. Chaetomugilins I-O, new potent cytotoxic metabolites from a marine-fish-derived Chaetomium species. Stereochemistry and biological activities. Tetrahedron 2009, 65, 7580-7586. [CrossRef]

74. Hu, X.; Wang, J.; Chai, J.; Yu, X.; Zhang, Y.; Feng, Y.; Qin, J.; Yu, H. Chaetomugilin J enhances apoptosis in human ovarian cancer A2780 cells induced by cisplatin through inhibiting pink1/parkin mediated mitophagy. Oncotargets Therap. 2020, 13, 9967-9976. [CrossRef]

75. Yamada, T.; Muroga, Y.; Tanaka, R. New azaphilones, seco-chaetomugilins A and D, produced by a marine-fish-derived Chaetomium globosum. Mar. Drugs 2009, 7, 249-257. [CrossRef] [PubMed]

76. Muroga, Y.; Yamada, T.; Numata, A.; Tanaka, R. 11- and 4'-epimers of chaetomugilin A, novel cytostatic metabolites from marine fish-derived fungus Chaetomium globosum. Helv. Chim. Acta 2010, 93, 542-549. [CrossRef]

77. Winter, J.M.; Sato, M.; Sugimoto, S.; Chiou, G.; Garg, N.K.; Tang, Y.; Watanabe, K. Identification and characterization of the chaetoviridin and chaetomugilin gene cluster in Chaetomium globosum reveal dual functions of an iterative highly-reducing polyketide synthase. J. Am. Chem. Soc. 2012, 134, 17900-17903. [CrossRef] [PubMed]

78. Prompanya, C.; Dethoup, T.; Bessa, L.J.; Pinto, M.M.M.; Gales, L.; Costa, P.M.; Silva, A.M.S.; Kijjoa, A. New isocoumarin derivatives and meroterpenoids from the marine sponge-associated fungus aspergillus similanensis sp. Nov. Kufa 0013. Mar. Drugs 2014, 12, 5160-5173. [CrossRef]

79. Prompanya, C.; Fernandes, C.; Cravo, S.; Pinto, M.M.M.; Dethoup, T.; Silva, A.M.S.; Kijjoa, A. A new cyclic hexapeptide and a new isocoumarin derivative from the marine sponge-associated fungus Aspergillus similanensis KUFA 0013. Mar. Drugs 2015, 13, 1432-1450. [CrossRef]

80. Masuda, Y.; Tanaka, R.; Ganesan, A.; Doi, D. Structure revision of similanamide to PF1171C by total synthesis. J. Nat. Prod. 2015, 78, 2286-2291. [CrossRef]

81. Kai, K.; Yoshikawa, H.; Kuo, Y.-H.; Akiyama, K.; Haysahi, H. Determination of absolute structures of cyclic peptides, PF1171a and PF1171c, from unidentified Ascomycete OK-128. Biosci. Biotech. Biochem. 2010, 74, 1309-1311. [CrossRef]

82. Pang, X.; Lin, X.; Wang, P.; Zhou, X.; Yang, B.; Wang, J.; Liu, Y. Perylenequione derivatives with anticancer activities isolated from the marine sponge-derived fungus, Alternaria sp. SCSIO41014. Mar. Drugs 2018, 16, 280. [CrossRef]

83. Ur Rehman, S.; Yang, L.-J.; Zhang, Y.-H.; Wu, J.-S.; Shi, T.; Haider, W.; Shao, C.-L.; Wang, C.-Y. Sorbicillinoid derivatives from sponge-derived fungus Trichoderma reesei (HN-2016-018). Front. Microbiol. 2020, 11, 1334. [CrossRef]

84. Jiang, W.; Ye, P.; Chen, C.T.A.; Wang, K.; Liu, P.; He, S.; Wu, X.; Gan, L.; Ye, Y.; Wu, B. Two novel hepatocellular carcinoma cycle inhibitory cyclodepsipeptides from a hydrothermal vent crab-associated fungus Aspergillus clavatus C2WU. Mar. Drugs 2013, 11, 4761-4772. [CrossRef] 
85. Takahashi, K.; Sakai, K.; Nagano, Y.; Sakaguchi, S.O.; Lima, A.O.; Pellizari, V.H.; Iwatsuki, M.; Takishita, K.; Nonaka, K.; Fujikura, K.; et al. Cladomarine, a new anti-saprolegniasis compound isolated from the deep-sea fungus, Penicillium coralligerum YK-247. J. Antibiot. 2017, 70, 911-914. [CrossRef]

86. Liu, L.; Zheng, Y.-Y.; Shao, C.-L.; Wang, C.-Y. Metabolites from marine invertebrates and their symbiotic microorganisms: Molecular diversity discovery, mining, and application. Mar. Life Sci. Technol. 2019, 1, 60-94. [CrossRef]

87. Marchese, P.; Young, R.; O'Connell, E.; Afoullouss, S.; Baker, B.J.; Allcock, A.L.; Barry, F.; Murphy, J.M. Deep-sea coral garden invertebrates and their associated fungi are genetic resources for chronic disease drug discovery. Mar. Drugs 2021, $19,390$. [CrossRef]

88. Rust, M.; Helfrich, E.J.N.; Freeman, M.F.; Nanudorn, P.; Field, C.M.; Rückert, C.; Kündig, T.; Page, M.J.; Webb, V.L.; Kalinowski, J.; et al. A multiproducer microbiome generates chemical diversity in the marine sponge Mycale hentscheli. Proc. Natl. Acad. Sci. USA 2020, 117, 9508-9518. [CrossRef]

89. Wilson, M.C.; Mori, T.; Ruckert, C.; Uria, A.R.; Helf, M.J.; Takada, K.; Gernert, C.; Steffens, U.A.; Heycke, N.; Schmitt, S.; et al. An environmental bacterial taxon with a large and distinct metabolic repertoire. Nature 2014, 506, 58-62. [CrossRef] [PubMed]

90. Schroeckh, V.; Scherlach, K.; Nützmann, H.-W.; Shelest, E.; Schmidt-Heck, W.; Schuemann, J.; Martin, K.; Hertweck, C.; Brakhage, A.A. Intimate bacterial-fungal interaction triggers biosynthesis of archetypal polyketides in Aspergillus nidulans. Proc. Natl. Acad. Sci. USA 2009, 106, 14558-14563. [CrossRef] [PubMed]

91. Chiang, Y.-M.; Szewczyk, E.; Nayak, T.; Davidson, A.D.; Sanchez, J.F.; Lo, H.-C.; Ho, W.-H.; Simityan, H.; Kuo, E.; Praseuth, A.; et al. Molecular genetic mining of the Aspergillus secondary metabolome: Discovery of the emericellamide biosynthetic pathway. Chem. Biol. 2008, 15, 527-532. [CrossRef]

92. Shwab, E.K.; Bok, J.W.; Tribus, M.; Galehr, J.; Graessle, S.; Keller, N.P. Histone deacetylase activity regulates chemical diversity in Aspergillus. Eukaryot. Cell 2007, 6, 1656-1664. [CrossRef] [PubMed]

93. Zhu, J.X.; Ding, L.; He, S. Discovery of a new biphenyl derivative by epigenetic manipulation of marine-derived fungus Aspergillus versicolor. Nat. Prod. Res. 2019, 33, 1191-1195. [CrossRef]

94. He, X.; Zhang, Z.; Chen, Y.; Che, Q.; Zhu, T.; Gu, Q.; Li, D. Varitatin A, a highly modified fatty acid amide from Penicillium variabile cultured with a DNA methyltransferase inhibitor. J. Nat. Prod. 2015, 78, 2841-2845. [CrossRef]

95. He, X.; Zhang, Z.; Che, Q.; Zhu, T.; Gu, Q.; Li, D. Varilactones and wortmannilactones produced by Penicillium variabile cultured with histone deacetylase inhibitor. Arch. Pharmacal Res. 2018, 41, 57-63. [CrossRef]

96. Wang, L.; Li, M.; Tang, J.; Li, X. Eremophilane sesquiterpenes from a deep marine-derived fungus, Aspergillus sp. SCSIOW2, cultivated in the presence of epigenetic modifying agents. Molecules 2016, 21, 473. [CrossRef]

97. Beau, J.; Mahid, N.; Burda, W.N.; Harrington, L.; Shaw, L.N.; Mutka, T.; Kyle, D.E.; Barisic, B.; van Olphen, A.; Baker, B.J. Epigenetic tailoring for the production of anti-iinfective cytosporones from the marine fungus Leucostoma persoonii. Mar. Drugs 2012, 10, 762-774. [CrossRef] [PubMed]

98. Zhang, W.; Shao, C.-L.; Chen, M.; Liu, Q.-A.; Wang, C.-Y. Brominated resorcylic acid lactones from the marine-derived fungus Cochliobolus lunatus induced by histone deacetylase inhibitors. Tetrahedron Lett. 2014, 55, 4888-4891. [CrossRef]

99. Zahner, H. What are secondary metabolites? Folia Microbiol. 1979, 24, 435-443. [CrossRef] [PubMed]

100. Bu'Lock, J.D.; Nisbet, L.J.; Winstanley, D.J. Bioactive Microbial Products: Search and Discovery; Academic Press: London, UK, 1982; Zahner Chapter; p. 148. ISBN 0-12-140750-0. [CrossRef]

101. Chiang, Y.-M.; Lee, K.-H.; Sanchez, J.F.; Keller, N.P.; Wang, C.C.C. Unlocking fungal cryptic natural products. Nat. Prod. Comm. 2009, 4, 1505-1510. [CrossRef]

102. Hemphill, C.F.P.; Sureechatchaiyan, P.; Kassack, M.U.; Orfali, R.S.; Lin, W.; Daletos, G.; Proksch, P. OSMAC approach leads to new fusarielin metabolites from Fusarium tricinctum. J. Antibiot. 2017, 70, 726-732. [CrossRef] [PubMed]

103. Lin, Z.; Zhu, T.; Wei, H.; Zhang, G.; Wang, H.; Gu, Q. Spicochalasin A and new aspochalasins from the marine-derived fungus Spicaria elegans. Eur. J. Org. Chem. 2009, 3045-3051. [CrossRef]

104. Wu, H.; Ding, Y.; Hu, K.; Long, X.; Qu, C.; Puno, P.-T.; Deng, J. Bioinspired network analysis enabled divergent syntheses and structure revision of pentacyclic cytochalasans. Angew. Chem. Int. Ed. 2021, 60, 15963-15971. [CrossRef] [PubMed]

105. Liu, R.; Gu, Q.; Zhu, W.; Cui, C.; Fan, G.; Fang, Y.; Zhu, T.; Liu, H. 10-phenyl-[12]-cytochalasins Z7, Z8, and Z9 from the marine-derived fungus Spicaria elegans. J. Nat. Prod. 2006, 69, 871-875. [CrossRef]

106. Liu, R.; Lin, Z.; Zhu, T.; Fang, Y.; Gu, Q.; Zhu, W. Novel open-chain cytochalasins from the marine-derived fungus Spicaria elegans. J. Nat. Prod. 2008, 71, 1127-1132. [CrossRef]

107. Shang, Z.; Li, X.-M.; Li, C.-S.; Wang, B.-G. Diverse secondary metabolites produced by marine-derived fungus Nigrospora sp. MA75 on various culture media. Chem. Biodiv. 2012, 9, 1338-1348. [CrossRef]

108. Huang, H.; Wang, F.; Luo, M.; Chen, Y.; Song, Y.; Zhang, W.; Zhang, S.; Ju, J. Halogenated anthraquinones from the marine-derived fungus Aspergillus sp. SCSIO F063. J. Nat. Prod. 2012, 75, 1346-1352. [CrossRef]

109. Wang, Y.; Lu, Z.; Sun, K.; Zhu, W. Effects of high salt stress on secondary metabolite production in the marine-derived fungus Spicaria elegans. Mar. Drugs 2011, 9, 535-542. [CrossRef] [PubMed]

110. Luan, Y.; Wei, H.; Zhang, Z.; Che, Q.; Liu, Y.; Zhu, T.; Mándi, A.; Kurtán, T.; Gu, Q.; Li, D. Eleganketal A, a highly oxygenated dibenzospiroketal from the marine-derived fungus Spicaria elegans KLA03. J. Nat. Prod. 2014, 77, 1718-1723. [CrossRef] [PubMed]

111. Yun, K.; Feng, Z.; Choi, H.D.; Kang, J.S.; Son, B.W. New production of (R)-(-)-5-bromomellein, a dihydroisocoumarin derivative from the marine-derived fungus Aspergillus ochraceus. Chem. Nat. Compd. 2013, 49, 24-26. [CrossRef] 
112. Wang, F.-Z.; Wei, H.-J.; Zhu, T.-J.; Li, D.-H.; Lin, Z.-J.; Gu, Q.-Q. Three new cytochalasins from the marine-derived fungus Spicaria elegans KLA03 by supplementing the cultures with L- and D-tryptophan. Chem. Biodiv. 2011, 8, 887-894. [CrossRef] [PubMed]

113. Chen, Y.-X.; Xu, M.-Y.; Li, H.J.; Zeng, K.-J.; Ma, W.-Z.; Tian, G.-B.; Xu, J.; Yang, D.-P.; Lan, W.-J. Diverse secondary metabolites from the marine-derived fungus Dichotomomyces cejpii F31-1. Mar. Drugs 2017, 15, 339. [CrossRef] [PubMed]

114. Jiang, W.; Zhong, Y.; Shen, L.; Wu, X.; Ye, Y.; Chen, C.-T.A.; Wu, B. Stress-driven discovery of natural products from extreme marine environment-Kueishantao hydrothermal vent, a case study of metal switch valve. Curr. Org. Chem. 2014, 18, 925-934. [CrossRef]

115. Ye, P.; Shen, L.; Jiang, W.; Ye, Y.; Chen, C.T.; Wu, X.; Wang, K.; Wu, B. Zn-driven discovery of a hydrothermal vent fungal metabolite clavatustide $C$, and an experimental study of the anti-cancer mechanism of clavatustide B. Mar. Drugs 2014, 12, 3203-3217. [CrossRef]

116. Ding, C.; Wu, X.; Auckloo, B.N.; Chen, C.-T.A.; Ye, Y.; Wang, K.; Wu, B. An unusual stress metabolite from a hydrothermal vent fungus Aspergillus sp. WU 243 induced by cobalt. Molecules 2016, 21, 105. [CrossRef]

117. Wang, W.-J.; Li, D.-Y.; Li, Y.-C.; Hua, H.-M.; Ma, E.-L.; Li, Z.-L. Caryophyllene sesquiterpenes from the marine-derived fungus Ascotricha sp. ZJ-M-5 by the one strain-many compounds strategy. J. Nat. Prod. 2014, 77, 1367-1371. [CrossRef]

118. Chen, X.-W.; Li, C.-W.; Cui, C.B.; Hua, W.; Zhu, T.-J.; Gu, Q.-Q. Nine new and five known polyketides derived from a deep sea-sourced Aspergillus sp. 16-02-1. Mar. Drugs 2014, 12, 3116-3137. [CrossRef] [PubMed]

119. Chen, X.W.; Li, C.W.; Hua, W.; Wu, C.J.; Cui, C.B.; Zhu, T.J.; Gu, Q.Q. Metabolites of Aspergillus sp. 16-02-1 isolated from a deep sea sediment and preliminary test of their antitumor and antifungal activities. Chin. J. Mar. Drugs 2013, 32, 1-10.

120. Guo, W.; Zhang, Z.; Zhu, T.; Gu, Q.; Li, D. Penicyclones A-E, antibacterial polyketides from the deep-sea-derived fungus Penicillium sp. F23-2. J. Nat. Prod. 2015, 78, 2699-2703. [CrossRef]

121. Wu, B.; Wiese, J.; Labes, A.; Kramer, A.; Schmaljohann, R.; Imhoff, J.F. Lindgomycin, an unusual antibiotic polyketide from a marine fungus of the Lindgomycetaceae. Mar. Drugs 2015, 13, 4617-4632. [CrossRef]

122. Liu, D.-S.; Rong, X.-G.; Kang, H.-H.; Ma, L.-Y.; Hamann, M.; Liu, W.-Z. Raistrickiones A-E from a highly productive strain of Penicillium raistrickii generated through thermo change. Mar. Drugs 2018, 16, 213. [CrossRef] [PubMed]

123. Christian, O.E.; Compton, J.; Christian, K.R.; Mooberry, S.L.; Valeriote, F.A.; Crews, P. Using jasplakinolide to turn on pathways that enable the isolation of new chaetoglobosins from Phomospis asparagi. J. Nat. Prod. 2005, 68, 1592-1597. [CrossRef] [PubMed]

124. Lin, Z.-J.; Zhu, T.-J.; Zhang, G.-J.; Wei, H.-J.; Gu, Q.-Q. Deoxycytochalasins from a marine-derived fungus Spicaria elegans. Can. J. Chem. 2009, 87, 486-489. [CrossRef]

125. Reen, J.; Romano, S.; Dobson, A.D.W.; O'Gara, F. The sound of silence: Activating silent biosynthetic gene cllusters in marine microorganisms. Mar. Drugs 2015, 13, 4754-4783. [CrossRef] [PubMed]

126. Romano, S.; Jackson, S.A.; Patry, S.; Dobson, A.D.W. Extending the "one strain many compounds" (OSMAC) principle to marine microorganisms. Mar. Drugs 2018, 16, 244. [CrossRef] [PubMed]

127. Miller, J.D.; Savard, M.E. Antibiotic activity of the marine fungus Leptosphaeria oraemaris. Proc. N. S. Inst. Sci. 1989, 39, 51-58. Available online: https:/ / dalspace.library.dalca / / handle/10222/35250 (accessed on 12 December 2021).

128. Masuma, R.; Yamaguchi, Y.; Noumi, M.; Omura, S.; Namikoshi, M. Effect of sea water concentration on hyphal growth and antimicrobial metabolite production in marine fungi. Mycoscience 2001, 42, 455-459. [CrossRef]

129. Mikolasch, A.; Hessel, S.; Salazar, M.G.; Neumann, H.; Manda, K.; Gōrdes, D.; Schmidt, E.; Thurow, K.; Hammer, E.; Lindequist, U.; et al. Synthesis of new $\mathrm{N}$-analogous corollosporine derivatives with antibacterial activity by laccase-catalyzed amination. Chem. Pharm. Bull. 2008, 56, 781-786. [CrossRef] [PubMed]

130. Roullier, C.; Bertrand, S.; Blanchet, E.; Peigné, M.; Robiou du Pont, T.; Guitton, Y.; Pouchus, Y.F.; Grovel, O. Time dependency of chemodiversity and biosynthetic pathways: An LC-MS metabolomic study of marine-sourced Penicillium. Mar. Drugs 2016, 14, 103. [CrossRef] [PubMed]

131. Abbanat, D.; Leighton, M.; Maiese, W.; Jones, E.B.; Pearce, C.; Greenstein, M. Cell wall active antifungal compounds produced by the marine fungus Hypoxylon oceanicum LL-15G256. I. Taxonomy and fermentation. J. Antibiot. 1998, 51, 296-302. [CrossRef]

132. Doshida, J.; Hasegawa, H.; Onuki, H.; Shimidzu, N. Exophilin A, a new antibiotic from a marine microorganism Exophiala pisciphila. J. Antibiot. 1996, 49, 1105-1109. [CrossRef]

133. Xu, B.; Yin, Y.; Zhang, F.; Li, Z.; Wang, L. Operating conditions optimization for (+)-terrein production in a stirred bioreactor by Aspergillus terreus strain PF-26 from marine sponge Phakellia fusca. Bioproc. Biosys. Engin. 2012, 35, 1651-1655. [CrossRef]

134. Pignatiello, J.J., Jr. An overview of the strategy and tactics of Tagaguchi. IEEE Trans. 1988, 20, 247-254. [CrossRef]

135. Plackett, R.L.; Burman, J.P. The design of optimum multifactorial experiments. Biometrika 1946, 33, 305-325. [CrossRef]

136. Cochran, W.G.; Cox, G.M. Experimental Designs; John Wiley and Sons: New York, NY, USA, 1957; p. 611. ISBN 9780471162049.

137. Du, L.; Zhu, T.J.; Fang, Y.C.; Liu, H.B.; Gu, Q.Q.; Zhu, W.M. Aspergiolide Aone, a novel anthraquinone derivative with naphtho[1,2,3-de]chromene-2,7-dione skeleton isolated from a marine-derived fungus Aspergillus glaucus. Tetrahedron 2007, 63, 1085-1088. [CrossRef]

138. Cai, M.-H.; Zhou, X.-S.; Sun, X.-Q.; Tao, K.-J.; Zhang, Y.-X. Statistical optimization of medium composition for aspergiolide A production by marine-derived fungus Aspergillus glaucus. J. Indust. Microbiol. Biotech. 2009, 36, 381-389. [CrossRef] 
139. Zhou, S.-1.; Wang, M.; Zhao, H.-S.; Huang, Y.-h.; Lin, Y.-y.; Tan, G.-h.; Chen, S.-1. Penicilazaphilone C, a new antineoplastic and antibacterial azaphilone from the marine fungus Penicillium sclerotiorum. Archiv. Pharmacal Res. 2016, 39, 1621-1627. [CrossRef] [PubMed]

140. Zhao, H.-G.; Wang, M.; Lin, Y.-Y.; Zhou, S.-L. Optimization of culture conditions for penicilazaphilone C production by a marine-derived fungus Penicillium sclerotiorum M-22H. Lett. Appl. Microbiol. 2017, 66, 222-230. [CrossRef]

141. Yu, Z.; Lang, G.; Kajahn, I.; Schmaljohann, R.; Imhoff, J.F. Scopularides A and B, cyclodepsipeptides from a marine sponge-derived fungus, Scopulariopsis brevicaulis. J. Nat. Prod. 2008, 71, 1052-1054. [CrossRef]

142. Ding, L.-J.; Yuan, W.; Liao, X.-J.; Han, B.-N.; Wang, S.-P.; Li, Z.-Y.; Xu, S.-H.; Zhang, W.; Lin, H.-W. Oryzamides A-E, cyclodepsipeptides from the sponge-derived fungus Nigrospora oryzae PF18. J. Nat. Prod. 2016, 79, 2045-2052. [CrossRef]

143. Kramer, A.; Paun, L.; Imhoff, J.F.; Kempken, F.; Labes, A. Development and validation of a fast and optimized screening method for enhanced production ofsecondary metabolites using the marine Scopulariopsis brevicaulis strain LF580 producing anti-cancer active scopularide A and B. PLoS ONE 2014, 9, e103320. [CrossRef] [PubMed]

144. Kramer, A.; Beck, H.C.; Kumar, A.; Kristensen, L.P.; Imhoff, J.F.; Labes, A. Proteomic analysis of anti-cancerous scopularide production by a marine Microascus brevicaulis strain and its UV mutant. PLoS ONE 2015, 10, e0140047. [CrossRef] [PubMed]

145. Lukassen, M.B.; Saei, W.; Sondergaard, T.E.; Tamminen, A.; Kumar, A.; Kempken, F.; Wiebe, M.G.; Sørensen, J.L. Identification of the scopularide biosynthetic gene cluster in Scopulariopsis brevicaulis. Mar. Drugs 2015, 13, 4331-4343. [CrossRef]

146. Alberti, F.; Foster, G.D.; Bailey, A.M. Natural products from filamentous fungi and production by heterologous expression. Appl. Microbiol. Biotechnol. 2017, 101, 493-500. [CrossRef]

147. Boecker, S.; Grätz, S.; Kerwat, D.; Adam, L.; Schirmer, D.; Richter, L.; Schütze, T.; Petras, D.; Süssmuth, R.D.; Meyer, V. Aspergillus niger is a superior expression host for the production of bioactive fungal cyclodepsipeptides. Fungal Biol. Biotech. 2018, 5, 4. [CrossRef]

148. Chaichanan, J.; Wiyakrutta, S.; Pongtharangkul, T.; Isarangkul, D.; Meevootisom, V. Optimization of zofimarin production by an endophytic fungus, Xylaria sp. Acra L38. Braz. J. Microbiol. 2014, 45, 287-293. [CrossRef]

149. Reich, M.; Labes, A. How to boost marine fungal research: A first step towards a multidisciplinary approach by combining molecular fungal ecology and natural products chemistry. Mar. Gent. 2017, 36, 57-75. [CrossRef]

150. Nai, C.; Meyer, V. From axenic to mixed cultures: Technological advances accelerating a paradigm shift in microbiology. Trends Microbiol. 2018, 26, 538-554. [CrossRef] [PubMed]

151. Stierle, A.A.; Stierle, D.B.; Decato, D.; Priestley, N.D.; Alverson, J.B.; Hoody, J.; McGrath, K.; Klepacki, D. The berkeleylactones, antibiotic macrolides from fungal coculture. J. Nat. Prod. 2017, 80, 1150-1160. [CrossRef]

152. Nie, Y.; Yang, W.; Liu, Y.; Yang, J.; Lei, X.; Gerwick, W.H.; Zhang, Y. Acetylcholinesterase inhibitors and antioxidants mining from marine fungi: Bioassays, bioactivity coupled LC-MS/MS analyses and molecular networking. Mar. Life Sci. Technol. 2020, 2, 386-397. [CrossRef]

153. Lage, O.M.; Ramos, M.C.; Calisto, R.; Almeida, E.; Vasconcelos, V.; Vicente, F. Current screening methodologies in drug discovery for selected human diseases. Mar. Drugs 2018, 16, 279. [CrossRef]

154. Wang, W.; Zheng, G.; Lu, Y. Recent advances in strategies for the cloning of natural product biosynthetic gene clusters. Front. Bioeng. Biotechnol. 2021, 9, 692797. [CrossRef] [PubMed] 